HOUSEHOLD PARTICIPATION IN DOMESTIC WASTE DISPOSAL AND RECYCLING IN THE TSHWANE METROPOLITAN AREA: AN ENVIRONMENTAL EDUCATION PERSPECTIVE

by

AGNES JONTON KAMARA

submitted in part fulfilment of the requirements for the degree of

\title{
MASTER OF EDUCATION
}

in the subject

ENVIRONMENTAL EDUCATION

at the

UNIVERSITY OF SOUTH AFRICA

SUPERVISOR: DR L D M LEBELOANE

FEBRUARY 2006 


\section{DEDICATION}

This work is dedicated to my parents Mr. Alfred S. Samu and Mrs. Nyanda Samu, my husband Dr. Abdul Kamara, my children Fanta Brunhilde Kamara and Jonta Mariama Kamara; and to my aunty Ms. Brunhilde Goebel. 


\section{DECLARATION}

I, Agnes Jonton Kamara, hereby declare that this dissertation for the Master's Degree in Education with specialization in Environmental Education, at the University of South Africa has not previously been submitted for a degree at this or any other university, and it is my work in design and execution, and that all the sources I have used or quoted have been indicated and duly acknowledged by means of complete references. 


\section{ACKNOWLEDGEMENTS}

I wish to acknowledge and extend my sincere thanks and appreciation to the following people:

- Dr. L D M Lebeloane, my thesis supervisor and promoter, for guiding the work and providing valuable comments throughout the work. This research work would hardly have been possible without his encouragement and guidance.

- Mr. Litha Magingxa for assisting in data collection.

- Mrs. Jumi Aramide Olagoke for assisting in data collection.

- My dear husband Dr. Abdul B. Kamara for his unreserved support and encouragement; and our dearest children Fanta Brunhilde Kamara and Jonta Mariama Kamara who showed great understanding for my long hours of work, sometime with reduced attention to them, to accomplish this work. 


\section{SUMMARY}

The aim of this study was to investigate the factors influencing household awareness and participation in domestic waste disposal and recycling, focusing on environmental educational (EE), wealth and location of suburb. The study was carried out in four suburbs in the Tshwane Metropolitan Area (TMA), namely Waterkloof, Lynnwood, Sunnyside and Mamelodi.

A literature review was conducted, covering concepts of domestic waste management - waste prevention, collection, recycling and reuse, followed by household analysis using empirical data. The analysis shows that there is a low level of household awareness about the environmental implications of domestic waste management in TMA, and hence low level of participation in domestic waste sorting, disposal and recycling. Among relevant factors are the level of EE and income of the households across all suburbs. This calls attention to the need for strengthening EE not only in schools, but also in suburbs using both formal and informal outreach programmes.

\section{Key terms:}

Environmental education; Solid waste; Domestic waste management; Tshwane metropolitan area; Household awareness; Household participation; Domestic waste disposal; Domestic waste recycling; Household wealth; Location of suburbs. 


\section{TABLE OF CONTENTS}

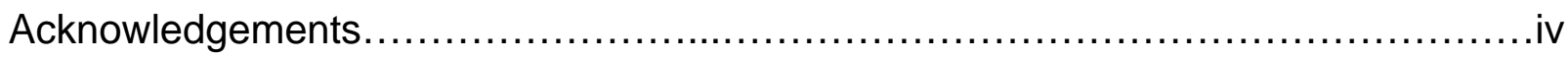

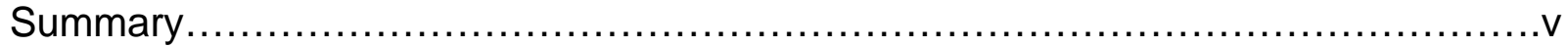

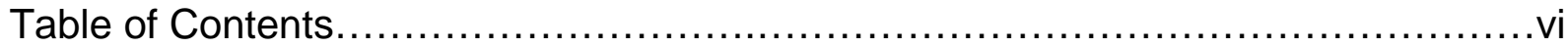

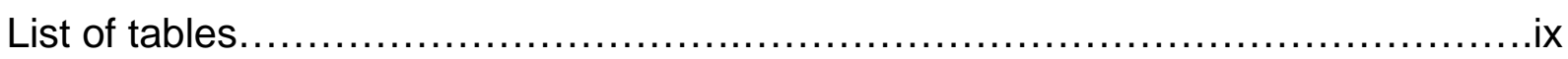

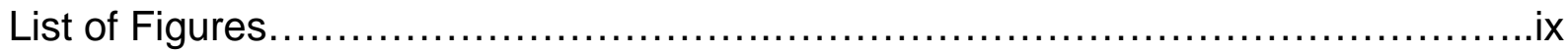

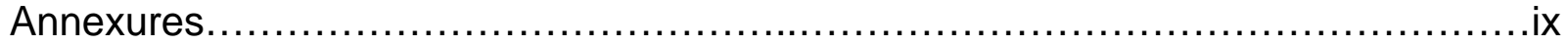

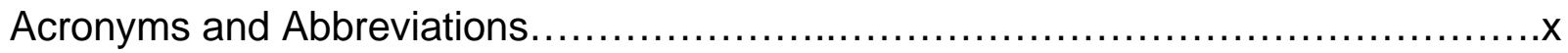

\section{CHAPTER $1 \quad$ ORIENTATION ..............................................................1}

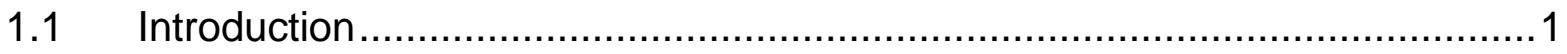

1.1.1 Global Concerns for Domestic Waste Management ...........................2

1.1.2 Status of Waste Problem in Developing Countries ...........................4

1.1.3 Waste Management Issues in South Africa ..................................5

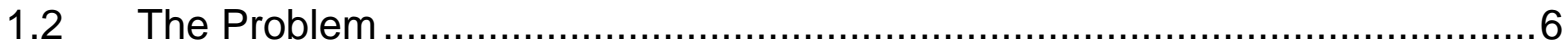

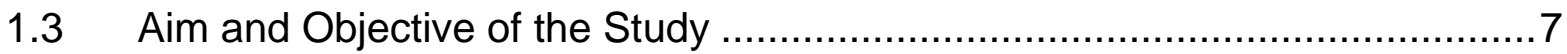

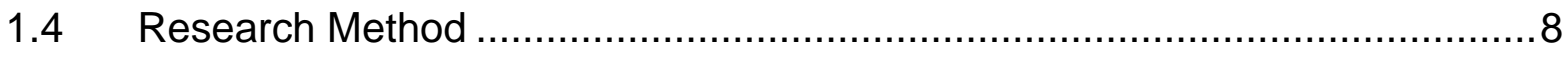

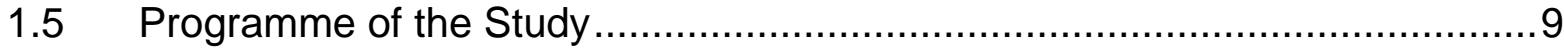

\section{CHAPTER 2 THEORETICAL PERSPECTIVES OF HOUSEHOLD PARTICIPATION IN DOMESTIC WASTE DISPOSAL AND RECYCLING ...................................................11}

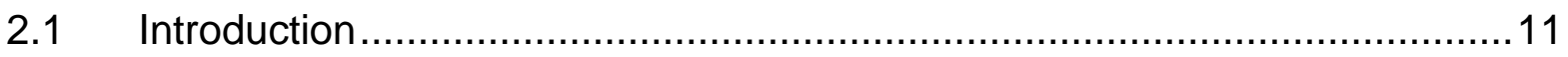

2.2 Definition of Terms and Concepts ........................................... 12

2.2.1 Concepts of Domestic Waste Management .................................. 12

2.2.1.1 Domestic Solid Waste Management ..................................................14

2.2.1.2 Re-use and Recycling................................................................... 14

2.2.1.3 Waste Prevention, Collection and Treatment ...................................15 
2.2.2 Defining Environmental Education (EE).....

2.2.3 Role of EE in Determining Participation in Domestic Waste Management19

2.3 Status of Domestic Waste Generation in South Africa ..............................23

2.4 Domestic Waste Management in Tshwane ..............................................26

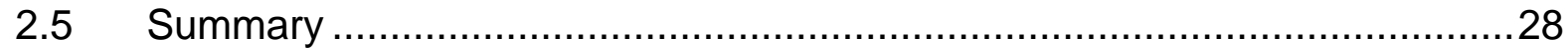

\section{CHAPTER 3 EMPIRICAL INVESTIGATION OF HOUSEHOLD PARTI- . CIPATION IN DOMESTIC WASTE MANAGEMENT ......30}

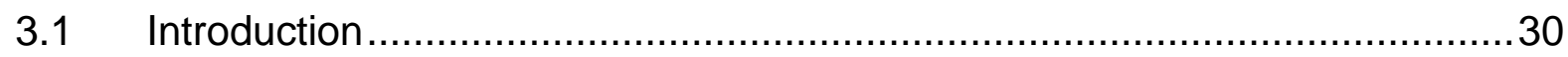

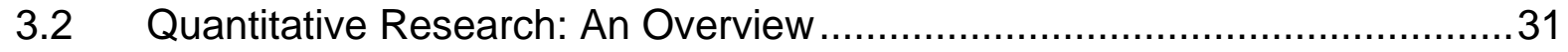

3.2.1 The Purpose of the Quantitative Research ...........................................33

3.2.2 Sampling Procedure in Quantitative Research .....................................34

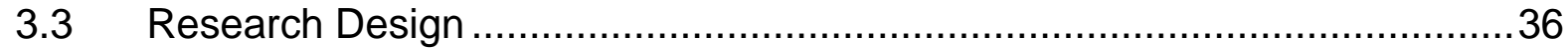

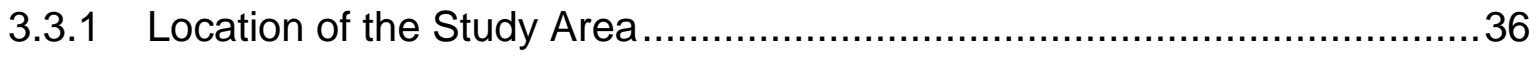

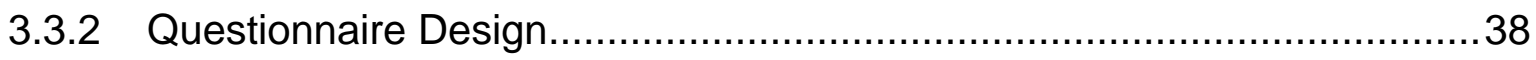

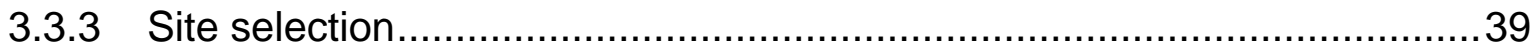

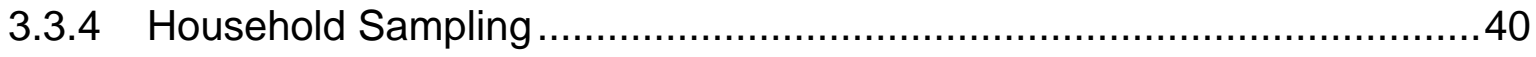

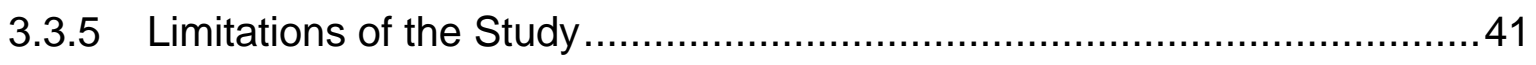

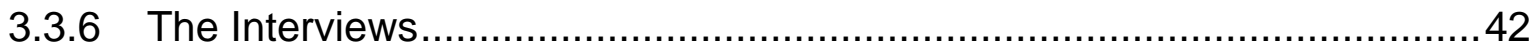

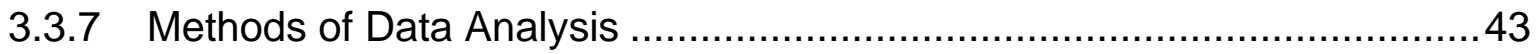

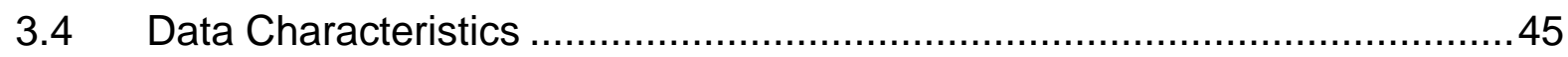

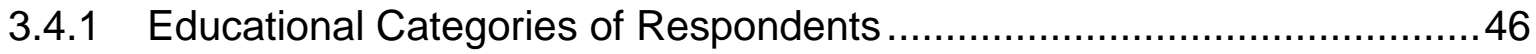

3.4.2 Household Characteristic by Education Level....................................47

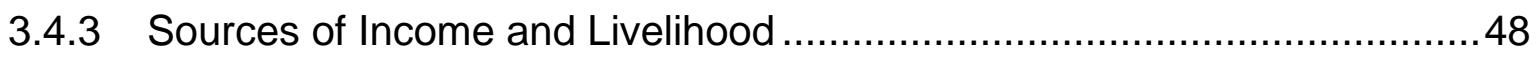

3.4.4 Household Characteristics by Wealth and Suburb .................................49

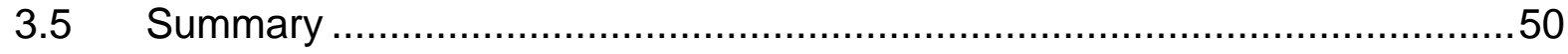

\section{CHAPTER 4 RESULTS OF THE EMPIRICAL ANALYSIS AND}

DISCUSSION...............................................................52

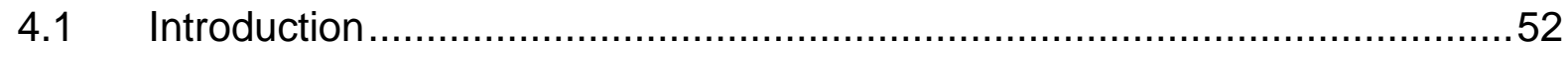


4.2 Awareness in Domestic Waste Management in TMA ...............................53

4.3 Household Participation in Domestic Waste Disposal and Recycling in TMA...

4.3.1 Domestic Waste Disposal and Recycling by Suburb (Lynnwood, Mamelodi,

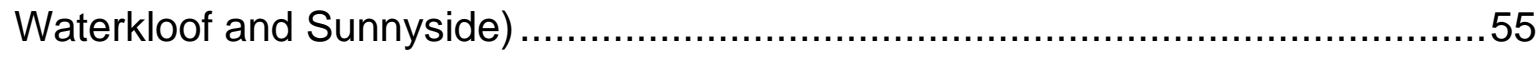

4.3.2 Waste Recycling and Disposal by Income and Wealth .........................5 57

4.3.3 Domestic Waste Disposal and Recycling by Educational Level................59

4.4 Factors Affecting Household Participation in Domestic Waste Recycling and

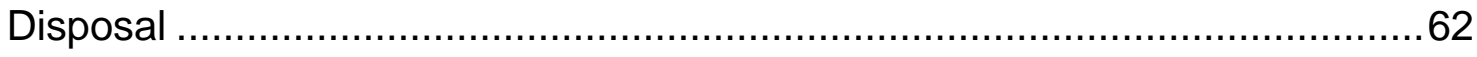

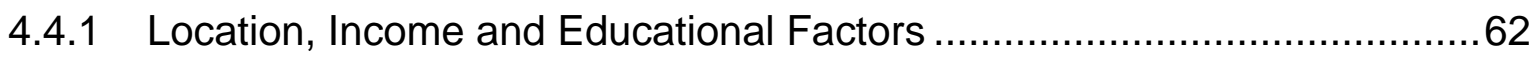

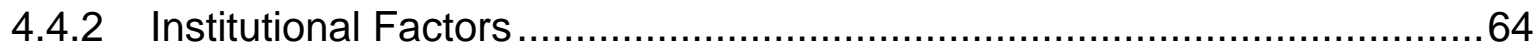

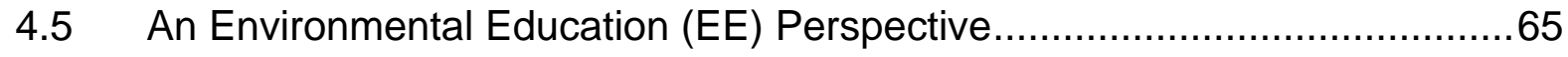

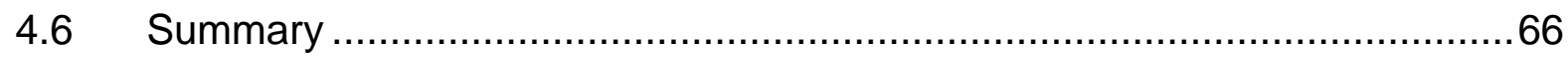

\section{CHAPTER 5 SUMMARY OF FINDINGS AND RECOMMENDATIONS}

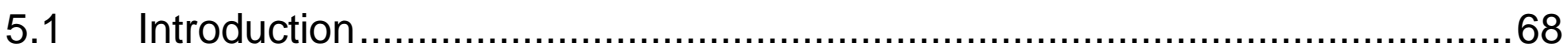

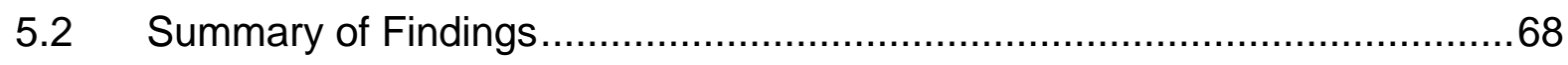

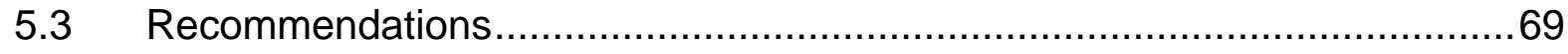

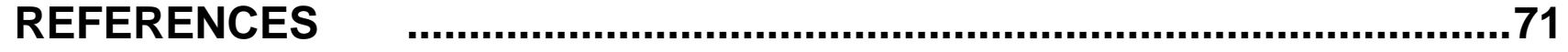

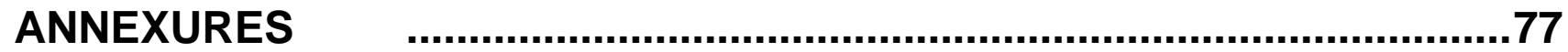




\section{LIST OF TABLES}

Table 1: $\quad$ Basic Characteristics of Sample Households 46

Table 2: $\quad$ Participation in Waste Management by Suburb 56

Table 3: $\quad$ Participation in Waste Management by Income and Wealth 58

Table 4: $\quad$ Participation in Waste Management by Educational Level 61

\section{LIST OF FIGURES}

Figure 1: $\quad$ The Waste Management Ladder and the Need for EE 20

Figure 2: $\quad$ Location of the Tshwane Metropolitan Area 38

Figure 3: Opinions on the Relevance of Waste Sorting 54

\section{ANNEXURES}

Annexure 1: Detailed Research Questions of the Study 77

Annexure 2: Survey Questionnaires Used In the Study 77

Annexure 3: Educational Categories of Respondents 82

Annexure 4: Detailed Household Characteristics by Education 82

Annexure 5: Occupational Categories of Sample Households 83

Annexure 6: Reasons for Non-Participation of Households in Domestic Waste Sorting

Annexure 7: Detailed Household Characteristics by Suburb and Income Class

Annexure 8: Participation of Households in Domestic Waste Sorting

Annexure 9: What Do You Think Should be Done to Encourage More People to Participate in Domestic Waste Sorting and Management? 


\section{ACRONYMS AND ABBREVIATIONS}

$\begin{array}{ll}\text { AIDS } & \text { Acquired Immune Deficiency Syndrome } \\ \text { CPP } & \text { Country Position Papers } \\ \text { DEAT } & \text { Department of environmental Affairs and Tourism (South Africa) } \\ \text { EE } & \text { Environmental Education } \\ \text { HIV } & \text { Human Immunity Virus } \\ \text { IUCN } & \text { International Union for the Conservation of Nature } \\ \text { KSAB } & \text { Keep South Africa Beautiful } \\ \text { MDGs } & \text { Millennium Development Goals } \\ \text { NGO } & \text { Non-Governmental Organization } \\ \text { R } & \text { Rand (South African Currency) } \\ \text { SRS } & \text { Simple Random Sampling } \\ \text { RSA } & \text { Republic of South Africa } \\ \text { TMA } & \text { Tshwane Metropolitan Area } \\ \text { UNCCD } & \text { United Nations Convention to Combat Desertification } \\ \text { UNCED } & \text { United Nations Conference on Environment and Development } \\ \text { UN-HABITAT } & \text { United Nations Habitat } \\ \text { UNEP } & \text { United Nation Environmental Programme } \\ \text { UNPFA } & \text { United Nation Fund for Populations Studies } \\ \text { WSSD } & \text { World Summit on Sustainable Development }\end{array}$




\section{CHAPTER 1}

\section{ORIENTATION}

\subsection{INTRODUCTION}

Environmental issues are firmly entrenched at the centre of the world stage in all spheres of development activity, especially after the Second World War. This is exemplified by the number of international conferences and workshops which were held on the environment. This includes the Rio de Janeiro Earth Summit in 1992, which marked the beginning of relentless environmental campaigns across the world from developed to developing nations (Orr, 1992:3-23; UNCED, 1992:327-366; Palmer, 1998:37-38), followed by the World Summit on Sustainable Development (WSSD) which was held in Johannesburg, South Africa in 2002 which has defined critical targets for sustainable development, including the Millennium Development Goals (MDGs). These campaigns are largely in response to the alarming rate at which human activities are affecting the environment.

Human activities generate many by-products which are generally seen as useless and discarded as waste (Arms, 1991: 397-404; Palmer, 1998:35-77). These massive amounts of waste subsequently find its way into the ground, water and air every year (Day, 1998:17). High consumption lifestyles in many countries have major effects on 
how much domestic waste are produced by modern high-technology, while little effort is made to bring the same technology to bear on waste management and disposal (Palmer, 1998:35-77). Increasing population growth accompanied by rapid urbanization and industrialization has resulted in dramatic increases in the volumes of waste generated by modern societies. Increase in electricity and food consumption by humans and changing lifestyles generate a massive volume of domestic waste which creates a critical problem in the developed and developing countries (Palmer, 1998:35-77).

This study investigates the level of household participation in domestic waste disposal and recycling in the Tshwane Metropolitan Area (TMA), which is one of the urban centres with rapidly increasing population in South Africa. This chapter discusses the growing concerns over global and local domestic waste management issues and the status of this problem in South Africa. The objective, aim of the study as well as the research methods and programme of the study are also presented in this chapter.

\subsubsection{Global Concerns for Domestic Waste Management}

Global concerns for addressing environmental issues call for giving specific attention to pertinent global issues such as population growth and its implications for natural resources requirements to meet the increasing demand for food and energy (Simmons, 1996:163-170). The alarming rate of resource depletion and waste generation, associated with population growth and increasing urbanization, is posing a 
grave problem across the globe (Palmer \& Suggate, 1996:109-122). In particular waste discharges are already beginning to change the way the biosphere functions, and the depletion of the ozone layer and climate change are beginning to reduce the productivity of global ecosystems at a time when millions of people are looking for livelihoods and sustenance to be provided by the environment (Simmons, 1996:163170). While each of these problems generally require global attention, the issue of waste management - disposal and recycling - seems to be the most urgent especially in the developing world where domestic waste management technology is still limited (UN-Habitat, 1988: 12-29 ; Palmer, 1998:35-77). The rising standard of living in most parts of the world also implies changing tastes, and increased consumption of both energy and materials.

Increased production of human wastes due to changing life styles create a critical problem especially in developing countries such as South Africa, which often have more urgent issues to attend to, such as food insecurity and threats from epidemic and pandemic diseases, which includes HIVIAIDS, malaria, tuberculosis and so on (Coinstreau, 1987: 1-30; UNEP, 1994: 20-35). However, failure to adequately address waste management problems can only aggravate the health situation, as most tropical diseases bear a direct linkage to sanitary and hygienic standards (UNEP, 1994: 2035). In most cases, especially in the absence of a strong government commitment, stringent rules and regulations, the general tendency in big cities is for people to dispose of their domestic wastes as quickly and conveniently as possible, often leaving large volumes of more complex residual waste. This is evident in most 
unplanned cities especially in Africa, where huge piles of solid wastes are dumped in the outskirts, while waste-contaminated rivers form an unpleasant habitat for disease vectors and organisms (Beede \& Bloom, 1995: 133-150). This situation has now led most countries to include waste management in their Country Position Papers (CPPs) on the environment, clearly highlighting the relevance of domestic waste management and disposal (Miller, 2002: 523-524).

\subsubsection{Status of Waste Problem in Developing Countries}

In developing countries such as South Africa, in particular, getting control of various waste streams from households, congested market places and unplanned industries make their proper handling, treatment and disposal a serious problem (Coinstreau, 1987: 1-30). These wastes, which are often littered around in huge, unsorted quantities, eventually find their way in nearby streams and rivers, which subsequently become polluted (UNEP, 2002: 50-65). In many cases, these polluted water sources are used by large segments of the population, especially the poor, for multiple purposes, including drinking, laundering, washing and/or bathing. Outbreak of

diseases and other health hazards are not uncommon in such settings in most developing countries (Teurlings. 1993: 7-19). In other instances, the huge organic and nutrient loads of streams and rivers lead to extensive eutrophication, posing a serious threat to the stability of the ecosystem (UNEP, 2002: 50-65). 
Solutions to the above problems, especially in big cities in Africa and Asia do not seem to be in sight, especially with the ever increasing rural urban migration, which in sub-Saharan Africa currently stands at about $4 \%$ on the average (Beede \& Bloom, 1995: 133-150; UNPFA, 1999: 1-5). While hopes for alleviating the problem are generally not very good, many people believe that education, especially environmental education (EE), coupled with efforts by committed governments to create viable waste management institutions can go a long way in improving the situation. For these efforts to be successfully undertaken and implemented in a planned manner, there is a need for research to acquire knowledge and information, especially information pertaining to current status in various cities, as well as what determines peoples current engagement or disenchantment in waste management (UNPFA, 1999: 1-5).

\subsubsection{Waste Management Issues in South Africa}

South Africa is a middle-income country that counts among Africa's fast growing and strongest economies (DEAT, 1999: 1-5; Swilling \& Hutt, 1999). Various types of production activities in South Africa generate many by-products, which are usually discarded but often turn out to be sources of acute environmental hazards (DEAT, 2000: 2-7). Increasing population growth, accompanied by rapid urbanization and industrialization, increase the volume of waste generated in the country (DEAT, 2000: 2-7). In South Africa, some outcomes of increasing waste generation are beginning to be observed in various forms, which affect the environment and human health in many ways (DEAT, 2000: 2-7; Almorza et al. 2002: 75-105), as follows: 
1. Waste from human and industrial activities is aesthetically unattractive and impacts negatively on tourism by creating a blight on South Africa's beautiful landscape.

2. There is an increasing record of waste polluting air, soil, rivers and precious groundwater.

3. Wastes create health hazards to humans, particularly in areas where large amounts are dumped and not cleaned up, e.g. in informal settlements, etc.

4. Waste fills up landfill sites, which are becoming more difficult and costly to establish or reclaim.

In the main cities such as Cape Town, Durban, Johannesburg and Tshwane, efforts are clearly exerted and there are solid institutional frameworks in place to facilitate waste collection, transportation and management, including sorting, recycling, proper disposal (DEAT, 2000). However, there are clear evidences of massive accumulation of waste especially in poorer settlements around city outskirts and in townships, where there is need for attention to support waste management (Frewin, 1997: 12-13).

\subsection{THE PROBLEM}

The problem of this study is the growing trend of city pollution in South Africa through inappropriate waste management which is becoming evident in the Tshwane (Pretoria) Metropolitan Area (TMA). Large parts of Tshwane, especially poorer settlements, are becoming untidy due to improper domestic waste disposal and low participation in domestic waste recycling. This situation is becoming obvious particularly in the spontaneous settlements and around the city outskirts, which poses 
various environmental problems. This study investigates the role of environmental education, location of suburb and wealth in determining household participation in domestic waste disposal and recycling in TMA. The detailed research questions that create the need for this study are presented in Annexure 1.

\subsection{AIM AND OBJECTIVE OF THE STUDY}

The aim of the study is to investigate household participation in domestic waste disposal and recycling in Tshwane Metropolitan Area (TMA) from an environmental education perspective.

The objective of the study is to investigate the relevant factors affecting household participation in domestic waste disposal and recycling in TMA in the following ways:

- To investigate the level of household awareness about the importance of domestic waste sorting, disposal and recycling in the TMA;

- To investigate the role of environmental education (EE) and household income (wealth) in determining participation in domestic waste disposal and recycling in TMA;

- To investigate whether household location (suburb) has any effect on household participation in domestic waste disposal and recycling in TMA; and

- To investigate how environmental education can be used to minimize the problem of inappropriate domestic waste disposal in TMA. 


\subsection{RESEARCH METHOD}

There are many definitions of research, which vary widely among authors based on discipline and method applied (Waltz \& Bausell 1981:1; Mitchell \& Jolly 1992: 50-120; Neuman, 2000; Struwig \& Stead, 2001:3). According to Waltz \& Bausell (1981: 1), research is an investigative process to find out or get to know more about a topic. It is a structured enquiry that utilises justifiable scientific methodology that seeks to generate answers in the form of knowledge to be identified (Baxter, Hughes \& Tight (1996: 30-37); research is objective and is concerned with the truth of statements or facts. A common future shared by most definitions is that research entails the systematic investigation towards increasing the sum of knowledge. For the purpose of this study, research is defined as a systematic investigation towards generating knowledge (Neuman, 2000). That is, an investigation into the factors affecting household participation in domestic waste disposal and recycling in TMA from an environmental education perspective, focusing on household income (wealth), level of education and location of suburb.

There are two types of research methods, namely quantitative and qualitative. Quantitative research is the collection and analysis of data in numeric form (Neuman, 2000), while qualitative research involves the use of non-numeric data to describe and generate an understanding about a given phenomenon (Struwig \& Stead, 2001:3). The data for quantitative research are measurable, often through experiment or through questionnaires administered to respondents, and can be interpreted by means of statistical instruments (Struwig \& Stead, 2001:3). These interpretations can 
be simple arithmetic or statistical measures, such as central tendencies (arithmetic means, medians, mode), measures of dispersions such as the variance and standard deviations, as well as sophisticated quantitative analysis that entail the building, and estimation of quantitative models.

This study is largely quantitative and it utilizes data that is collected through household interviews using standard questionnaires designed for the purpose of this study. Quantitative research allows the selection of a representative sample from among the population to be investigated, which then allows an analysis that generate inferences for the entire population under investigation (Newman, 2000). In this study therefore the study questionnaires were administered in TMA for the purpose of exploring household participation in domestic waste disposal and recycling. The quantitative research method is appropriate for investigations dealing with the assessment of variables which can be measured or quantified using specific indicators. In this study, arithmetic means and standard deviations of levels of education, wealth and location of suburb are used to analyse variations across the sample households in terms of participation in waste disposal and recycling.

\subsection{PROGRAMME OF THE STUDY}

Chapter 2 presents theoretical perspectives of household participation in domestic waste disposal and recycling. Chapter 3 presents an overview of quantitative research methods and describes the method of data collection used in this study. It also 
presents the research design, including questionnaire design, sample selection, data collection, and characteristics of the sample households. Chapter 4 presents the results of the analysis while Chapter 5 gives a summary of findings and recommendations drawn from the study. 


\section{CHAPTER 2}

\section{THEORETICAL PERSPECTIVES OF HOUSEHOLD PARTICIPATION IN DOMESTIC WASTE DISPOSAL AND RECYCLING}

\subsection{INTRODUCTION}

This chapter focuses on the theoretical perspectives of household participation in domestic waste disposal and recycling. It presents a definition of terms and concepts relating to waste management in general and household participation in domestic waste disposal and recycling in particular. This is followed by a detailed discussion of various waste management methods, including waste prevention, collection, treatment, recycling and re-use. The chapter also discusses the concept of the 'waste management ladder', which is discussed in terms of 'environmentally preferred waste management methods'. These methods are analysed from an environmental education (EE) perspective, indicating the need for reinforcing environmental education for achieving highly preferred waste management methods. This is followed by a definition of EE, and a discussion of the role of EE in determining household participation in domestic waste disposal and recycling. The status of domestic waste generation and management in South Africa is then discussed, with a focus on the Tshwane Metropolitan Area (TMA). 


\subsection{DEFINITION OF TERMS AND CONCEPTS}

Concepts and terms which will be defined in this section include the following: household, participation, waste, solid waste, domestic waste, disposal, domestic disposal and domestic waste management, including domestic waste prevention, collection, treatment, recycling and re-use.

\subsubsection{Concepts of Domestic Waste Management}

Household is defined as a social unit, characterised by the sharing of the same dwelling house, with incomes that are pooled together for common use (Ellis, 1998: 14). For the purpose of this study, a household is defined as a social unit, comprised of people living in the same house, with a head, and pooling their incomes together for the management of their dwelling unit. This income is pooled together for food, shelter and other social needs, and for the general management of the household, including domestic waste management.

Participation is defined as getting involved in, or taking part in an activity by individuals and groups at all levels (Schwarz, 1993: 1236). For the purpose of this study, participation is defined as taking part in activities related to domestic solid waste disposal and recycling. Participation in domestic solid waste disposal and recycling is 
assessed at the household level, which is a critical level for domestic solid waste management, and is thus used as a unit of analysis of the study.

Waste generally refers to all unwanted and economically unusable materials that result from human activities, discarded purposefully or accidentally into the environment (UNEP, 1994; Gerrans, 1994; Van Beukering, et al., 1999: 30). There are various types of wastes generated from human activities, but the focus will be on domestic waste for the purpose of this study.

Domestic waste includes ordinary refuse, garbage, swill, rubbish and all forms of refuse from household activities, including human excreta. Thus domestic waste can be in the form of a solids or liquids, but the focus of this study will be on domestic solid waste.

Solid waste is general waste that is not a liquid or a gas, originating from industrial, domestic, municipal or agricultural sources (Miller, 2002: 518-519). This study focuses on domestic solid waste or solid waste that comes from domestic sources. Therefore for the purpose of this study, the term domestic solid waste is defined as the day-today rubbish, garbage and other forms of waste such as kitchen waste, food packaging, etc. originating from the household (http://www.cielap.org/infocent/ research/swaste.html [accessed on 15 June 2005]). Domestic waste disposal refers to all activities undertaken to get rid of domestic waste through sorting, collecting, 
transporting and disposal in a designated locations for treatment, recycling or re-use (Miller, 2002: 518-519).

\subsubsection{Domestic Solid Waste Management}

Domestic solid waste management encompasses the full range of management activities for domestic waste streams from the point of generating the waste to the point of disposal (Cointreau, et al., 1984; Baud and Shenk, 1994; Jones, 1995). These activities largely focus on resource recovery, which includes all the activities entailed in waste segregation, collection and processing, which are carried out taking into consideration economic viability of the material that is being recovered, e.g. for re-use and recycling (Beede and Bloom, 1995; van Beukering et al., 1999).

\subsubsection{Re-use and Recycling}

In this study, re-use and recycling are conceptualized as processes which provide an opportunity to capture some of the values from waste (Cointreau, et al., 1984). Of the two concepts, re-use is a simpler technique involving the re-utilisation of material in its end-use form without the necessity of further value addition or reprocessing. Recycling on the other hand, involves processing waste through conversion of parts or all of the waste into other useful material or to recover the original raw matter (Van Beukering, 1999; Van Beukering, 1999; Language and Van Blerk, 2000: 15-22; Clark, 2002: 31-33). While recycling and re-use provide an opportunity to regain residual value of waste material, or transform waste into usable raw materials, the resource requirements (energy, human resources, etc.) may sometimes be very great. These 
resource requirements can be greatly reduced through waste prevention, collection and treatment (Clark, 2002: 31-33).

\subsubsection{Waste Prevention, Collection and Treatment}

In this study, waste prevention is defined as all the activities and efforts of individuals and/or groups of individuals undertaken to minimise the volume of domestic waste generated, or generate waste in a form that facilitates easy collection, treatment and recycling (Cointreau, 1987; Smarck, 1997: 65; UNEP, 2002). The collection of waste and its recovery from different waste generating points is carried out by many agents such as formal and informal, which may represent a variety of organization structure and relationships (UNEP, 2002). In developing countries, solid waste management comes under the auspices of municipal bodies, which are the formal bodies responsible for the collection, removal and disposal of garbage from public places, and for the maintenance of dumping grounds. Specific areas of action on improving the efficiency of waste management, as summarised in UNEP (2002), include:

- waste prevention, minimization and waste detoxification;

- waste collection, transfer, transport and storage; and

- waste treatment, including waste disposal.

In the developed countries, different technologies may be available for waste treatment and recycling (Hadker, 1995). Generally, four main groups of waste treatment methods exist. These include: 
- Biological treatments: This generally entails the transformation of waste into organic matter via composting and aerobic transformation. This treated waste then becomes useful nutrients in agricultural production at home or on the farms.

- Incineration: Entails burning waste materials or substances with or without recovering some or all of the energy for re-use.

- Landfilling: This is a controlled method in developed countries, where waste is sorted and bio-degradable components disposed on controlled landfill sites.

- Dumping: Apart from these controlled methods, which are mostly prevalent in the developed and developing countries, uncontrolled methods can often not be avoided especially in the developing world. In large parts of Africa, for instance, solid waste is still dumped in the open air, in the ocean, or by burning it on site (Cointreau, et al., 1984). Such ways of disposal have irreversible and potentially harmful effects on both human health and the environment. These are clearly not methods that belong to sustainable waste management. It is alarming to note from a recent assessment that, such disposal methods are frequently employed in an estimated 175 sovereign nations and territories (Shah, 1997).

To enhance solid waste prevention and recycling, and to ease the problem of inappropriate disposal, certain methods of waste disposal are considered preferable to others under particular sets of conditions (Cointreau, 1987). The discussion of the relevance of these methods and their appropriateness under particular circumstances are discussed in relation to the level of environmental education required (EE). This 
creates a need for outlining the various definitions of EE and how these definitions are understood and applied in this study especially in the analytical section.

\subsubsection{Defining Environmental Education (EE)}

Defining EE is difficult both because of the all-embracing nature of its subject matter and the diversity of approaches and attitudes among those who promote environmental issues (Disinger, 1983; Smyth, 1983; Palmer, 1998). Though the definitions of EE are quite varied, they all seem to revolve around the conceptualisation of EE as a process, as well as a holistic and interdisciplinary approach to finding solutions to environmental problems.

Environmental education as a process entails the education and training that enable people to solve environmental problems. The holistic view is centred around the recognition of interaction between disciplines, involvement of individuals and groups at all levels, and the multi-layered nature of decision making processes and actions required for maintaining a sound environment (van Beukering et al., 1999). From a holistic perspective, Irwin (1991) describes EE as a worldwide socio-ecological phenomenon of many dimensions. He perceives EE as a sophisticated holistic concept, which embraces ecological knowledge and understanding, the entire population, its environmental relationships, ethics, politics, sociology, and public participation in decision making. 
Barlow (1997:212), also of the holistic view, defines EE as movement for fundamental educational reform in a rapidly changing world under increasing stress, both from human-induced change and from human nature itself. The definition stresses 'reform' in response to a changing world, which could be a good contribution from a dynamic perspective. However, this definition of EE is rather vague as it says little about the actual issues entailed in EE itself (ecological, social, economic and cultural aspects).

From a process perspective, Nightingale (1987), defines EE as an integrated process dealing with man's interrelationship with his natural and man-made surrounding, including the relationship of population growth, resource allocation and depletion, conservation, technology, urban and rural planning, to the total human environment. The merits of the definition lies in the recognition of the fact that EE is a process that involves man and his natural endowments, and human action could be structured to achieve positive environmental outcomes. Gough (1992) defines EE as a process, which develops awareness, knowledge and understanding of the environment, positive and balanced attitudes towards it and skills, which enable people to participate in determining the quality of the environment from local to an international level.

In this study, the IUCN definition of EE is adopted (Neal and Palmer, 1990:2), which defines EE as a process of recognising values and clarifying concepts in order to develop skills and attitudes necessary to understand and appreciate the interrelatedness among people, their cultures, and their biophysical surroundings. 
Since this study seeks to understand household participation in domestic waste disposal and recycling from an EE perspective, focusing on education, wealth and location of suburbs, this definition will be adopted. The definition provides the most appropriate elements that are critical for household participation in domestic waste management and for the application of EE to find solutions to problems of domestic waste management.

\subsubsection{Role of EE in Determining Participation in Domestic Waste Management}

This subsection deals with the role of environmental education in determining household participation in domestic waste management and recycling. The concept of the 'waste management ladder' is briefly introduced and used to explain the role of environmental education in facilitating domestic waste management.

In the waste management ladder (Figure 1), which this study has modified to indicate the role of EE in domestic waste management, Van Beukering et al. (1999) recognize that specific methods of waste management depend on the situation, available resources, stand of knowledge, technology, state of development and environmental priorities (Van Beukering et al., 1999). The authors conceptualise waste management methods into a ladder that gives an overview of the range of acceptable practices. The practices are not ranked in particular order but rather considered as a menu of available options, each of which should be critically assessed and applied under the appropriate conditions (Schall, 1995; van Beukering, et al., 1999). 


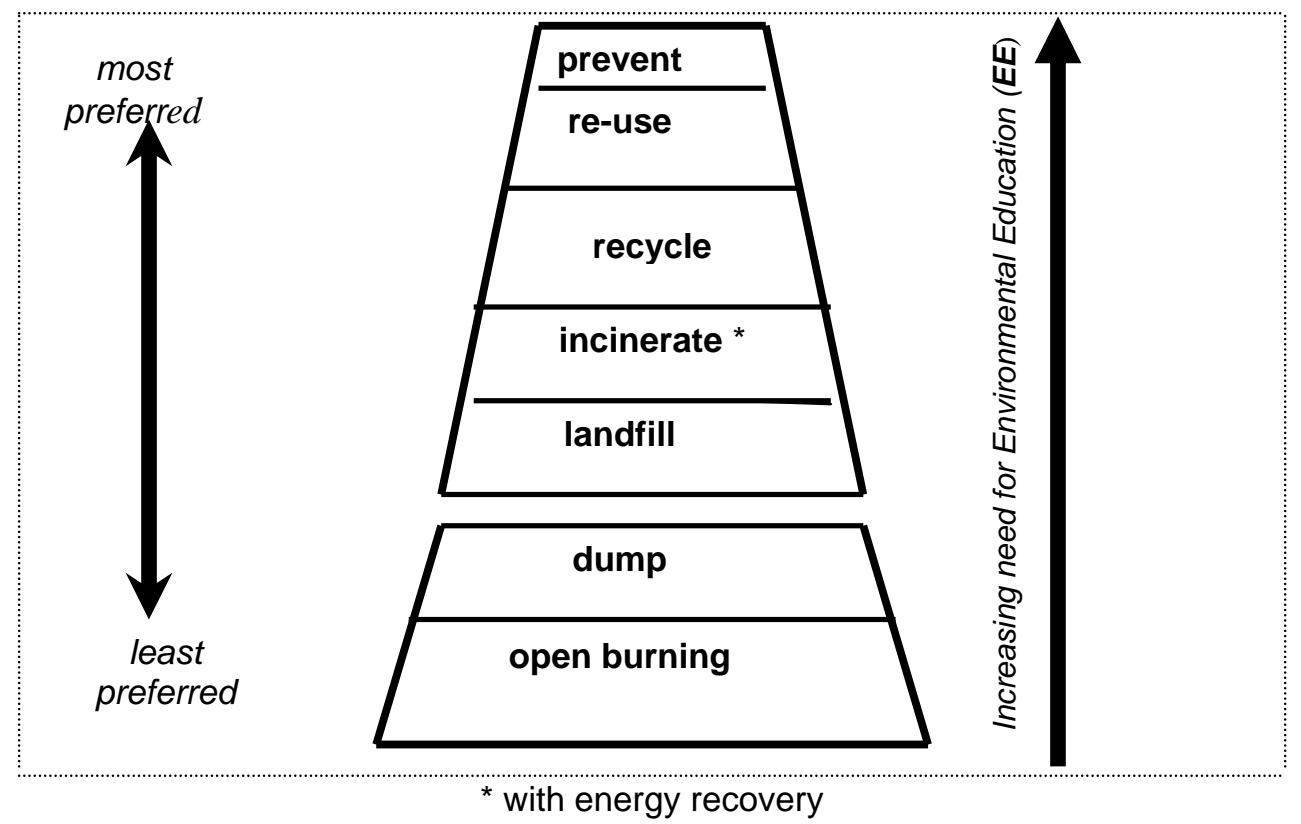

Figure 1: The Waste Management Ladder and the Need for EE Source: Author, (adapted from Van Beukering et al., 1999)

According to the conceptualisation, it is most desirable to prevent waste generation as far as possible. Since prevention in itself can never be absolute, efforts should be asserted to re-use and recycle household waste, especially solid waste, so as to reduce disposable components. Where possible, controlled incineration of disposable components (with energy recovery) is preferred over landfills and dumping. The least preferred methods, which cannot often be avoided, especially in developing countries are dumping, and open burning which is associated with air pollution (Schall, 1995).

From an environmental educational perspective, the need for having stronger environmental education programmes increases with rising preference for more environmentally friendly methods such as prevention, re-use and recycling as 
indicated in Figure 1. Thus, environmental education (EE) clearly plays a critical role in enhancing movement upward along the waste management ladder, from open burning through recycling and re-use to prevention.

Environmental education involves, among others, the acquisition of knowledge, skills, motivation and commitment to work individually and collectively towards the solution of existing environmental problems, and towards the prevention of new ones (Tilbury, 1992). At lower levels of education, among teenagers and the youth, EE aims at orientating young citizens and helping them in developing perceptions and positive actions towards environmental conservation and protection. At higher levels of education, the focus is on accumulating profound knowledge, and developing the necessary skills in working towards the management and improvement of environmental quality. At the professional level, EE aims at developing and creating a critical mass of specialists capable of managing environmental resources in a manner, which sustains its ecological values and integrity. Thus EE is undoubtedly a powerful medium through which higher levels on the ladder can be attained. That is, the harmony between people and nature, and between the environment and development (Mitra and Hale, 1993).

Most people view EE as the key to educating the young and old people, while at the same time enriching learning and supporting traditional educational objectives over a wide range of subjects and areas of experience (http://usinfo.gov/journals/itgic/0300 lijge/ gi05.htm [accessed on 8 June 2005]). There is now a growing consensus that 
peoples' attitude towards the environment has a direct relationship to their level of education, how much they know about the environment, its values and the need to protect those values (http://usinfo.gov/journals/itgic/0300/ijge/gj05.htm [accessed on 8 June 2005]). Thus community cleaning exercises or a 'keep the school clean' endeavour in a school, is likely to work effectively if preceded by some level of EE, telling the community members or school children the values of the environment and the need for keeping it in a clean state, waste disposal, sorting, participating in recycling programs, etc. (http://usinfo.gov/journals/itgic/0300/ijge/gi05.htm [accessed on 8 June 2005]). Through environmental education, in schools, through the media and across communities, people are capacitated to learn more about the environment and the value for its protection, and to know that even their own little efforts as individuals in proper waste disposal, and as a community in which they are a member, can make a big difference in contributing positively towards solving global environmental problems (Keep South Africa Beautiful Series, 1992a).

Balantyne and Oelofse (1989), and Garner (2001), among other scholars, endorse these facts by acknowledging that successes in waste management and disposal directly relate to the success of environmental education (EE), which according to them, further lies with many factors at various levels - individual, groups, community, and society as a whole (Garner, 2001: 43-44; Balantyne and Oelofse (1989: 25-32). At the institutional level, a key area of focus is the classroom, where environmental values can be imparted upon the young generation, the leaders of tomorrow (Keep South Africa Beautiful Series, 1992b; Balantyne and Packer, 1996). For the classroom 
to be a source of positive environmental attitudes, and for these attitudes to translate into everyday environmental behaviour, teachers have to be motivated to become committed, and must be given the necessary support and supplementary training to better integrate EE into their everyday class activities.

Other efforts that target the general public, such as media-based environmental education and the development of institutional frameworks for community cleaning, waste management, and so on, lie primarily with the state, either doing it directly or giving incentives to private sector organizations to get involved in especially urban sanitation. This recognition formed the underlying principle of the 'Keep South Africa Beautiful' (KSAB) campaign that was headed by the Department of National Health and Population Development in the 1990s (Keep South Africa Beautiful Series, 1992b). As stated in one of its Teacher's Guides, the objective of the campaign was to keep South Africa clean. The campaign had many avenues of reaching out to the masses, including community projects, school/youth projects, business projects entailing donation of litter bags, general awareness projects as well as competitions on radio, jingle art shows, and so on (Keep South Africa Beautiful, 1992a).

\subsection{STATUS OF DOMESTIC WASTE GENERATION IN SOUTH AFRICA}

The Department of Environmental Affairs and Tourism (DEAT), reports that South Africa generates over 42 million cubic meters of solid waste every year (DEAT, 1999). This is about $0.7 \mathrm{~kg}$ of solid waste per person per day, which is more typical of 
developed countries, than of a developing country ${ }^{1}$. The total urban waste (domestic waste) generation in the country is estimated at about 15 million tons per year; industries are reported to contribute about 25 million tons of waste per year (DEAT, 2000). In addition, 5 million cubic metres of hazardous waste is generated in South Africa per year (DEAT, 1999). These volumes are significant and can be detrimental to the environment if left unmanaged. South Africa's capacity to treat, store and dispose of high volumes of solid waste is limited, and it is predicted that five of the nine provinces will have landfill shortages in the next decade (DEAT, 2000).

Everyday, about 2.6 million cubic meters of domestic and commercial waste is processed at treatment plants, which is far less than the quantity generated (DEAT, 2000). This figure does not include agricultural and industrial wastes, which are the largest sources of waste in the country (DEAT, 2000). Given the rapid intensification of the interaction between inner cities and their outskirts (including townships), especially in terms of migration and expanding urbanization, it is imperative to consider improving on domestic waste disposal and management systems, if future negative impacts and environmental consequences are to be minimized or mitigated (DEAT, 2000).

Although South Africa is very committed to environmental management and is currently a signatory to many international agreements (e.g. The Kyoto Protocol, etc.) and environmental conventions such as the International Convention on Trade in

\footnotetext{
${ }^{1}$ By comparison the figures for the UK is $0.7 \mathrm{~kg}, 0.87 \mathrm{~kg}$ in Singapore, and $0.3 \mathrm{~kg}$ in Nepal (Arendse and Godfrey, 2002).
} 
Endangered Species, the Convention on Biodiversity Conservation ${ }^{2}$, and so on. However, putting these into reality is a big problem (DEAT, 2000). The problem has largely to do with the institutional framework for implementation, as well as skewed nature of income distribution in the country, which makes waste management issues virtually non-existent in certain affluent parts of cities where people can afford to pay for waste disposal, while other settlements with relatively poor populations have to grapple with the acquisition of basic life necessities, with relatively little attention to waste management. With this controversial setting in most metropolitan areas, the issue of domestic waste management and disposal can sometimes become so hot a debate that often reaches higher political heights (Ryan, 2000: 7-10; http://www.environment.gov.za/PolLeg/Agreements/2003Apr30/green leaders 30042 003.html [accessed on 9 August 2003]). A good example in the past is the case of the plastic bags in 2002. The bags were viewed by environmental activists and policymakers as unpleasant sources of pollution in various cities, including the Tshwane Metropolitan Area (TMA) (http://www.environment .gov.za/NewsMedia/ MedStat/ 2003May5/plastic bags 05052003.html [accessed 9 August 2003]). While there was a consensus that the bags are littered around primarily because they are given out free of charge to buyers in stores, getting a legislation to prohibit the free gift of the bags became a public problem. When the situation was finally sorted out and people started paying for the bags, they immediately resorted to cleaning the bags for reuse rather than dumping, bringing a dramatic end to the long standing problem of

\footnotetext{
${ }^{2}$ South Africa is a member of various international conventions and international agreements, including the Kyoto Protocol, the convention on "International Convention on Trade in Endangered Species, the Convention on Biodiversity, the Convention of the Trans-boundary Movement of Hazardous Waste, UN Convention to Combat Desertification (UNCCD), etc.
} 
haphazardly littering plastic bags (http://www.environment.gov.za/NewsMedia /MedStat/2003May5/ plastic bags 05052003 html [accessed 9 August 2003]).

The waste management scheme in South Africa entails a collection system in garbage containers at the household level in large cities such as Tshwane (DEAT, 2000). Households are charged on a monthly basis for the collection. Garbage sorting is not very much emphasised, though few households sort out bottles and metallic wastes. However, organic wastes such as decomposable garbage and inorganic wastes (such as plastics, etc.) are hardly sorted and are disposed of in mixed state in garbage containers. In the country side, collection is done at collection points with large containers that are designed to serve several households (DEAT, 2000).

\subsection{DOMESTIC WASTE MANAGEMENT IN TSHWANE}

Tshwane is the new name for Pretoria, which is derived from the African historical roots of the town. In the Tshwane Metropolitan Area (TMA), local authorities are primarily responsible for waste collection. There are two major forms of household waste collection in Tshwane in which TMA is located. The older form of collection requires households to bring their trash bins outside once a week, and a trash vehicle comes on a designated day in the week to pick it up. Households served by this method of collection are usually required to pay a certain fee per month (DEAT, 2000). In addition to this method, there is also the practice whereby people, especially unemployed people, collect papers, empty drink cans, etc., for nothing which they bring to the centre and get paid at approximately 20 cents per kilogram. This method 
has proved to be useful and efficient since the payment is a real incentive to the collectors who make every effort to recover recyclable scrap products and papers, which would otherwise have ended on landfill sites as environmental hazard.

The level of general waste collection service differs for different areas of Tshwane, and varies from non-serviced to fully serviced areas (RSA, 1999). Although waste collection is an integral part of waste management in the entire country, attention has in the past mainly focused largely on disposal. The proportion of waste which remains uncollected is increasing in South Africa as a whole, and it is estimated that more than 20 million households, mostly in rural and informal peri-urban and urban communities, do not receive acceptable waste management services (RSA, 1999; DEAT, 2000).

Human population in South African urban centres such as Tshwane is generally high (http://www.statssa.gov.za/census01/html/C2001SumReport.asp [assessed 27 June 2005]). Waste collection systems such as kerbside collection are feasible and practicable in established urban townships with infrastructure, but are not appropriate in rural settlements. In low-density settlements such as rural areas, waste is traditionally buried in pits situated on each property, so that waste collection systems are not required. Formerly, waste collection systems were imposed on communities without adequate consultation (RSA, 1999). This situation resulted in the services being discredited by members of some of the recipient communities. Also, efforts for awareness creation were focused on issues such as housing, health and 
unemployment. There was a limited awareness of waste management among the public, which contributed to the attitude of non-payment of service fees (RSA, 1999).

Waste collection coverage in South African cities is generally highest in the 'urban core' and is lowest in the scattered settlement. In Tshwane, the 'urban-core' corresponds to Lynnwood and Waterkloof, Sunnyside and so on, while the scattered settlements include townships such as Mamelodi among others.

This difference in coverage also relates to the types of services provided. In some scattered settlements and townships, garbage containers are centrally placed at collection points. In some instances, the central collection containers are located such that the distances between waste generation and collection points are often long (DEAT, 2000). In townships were this kind of situations are observed, indiscriminate littering, illegal dumping and burning of waste often become unavoidable, worsening off environmental problems (RSA, 1999).

\subsection{SUMMARY}

In this chapter, a theoretical perspective of household participation in domestic waste management has been presented. The terms and concepts relevant to the study have been defined and discussed. The term 'environmental education' (EE), has also been defined in the context in which it is used in this study, and its role in determining household participation in domestic waste management has been discussed. 
From the discussion in the chapter, especially in Section 2.2.2, it can be concluded that environmental education has a positive role in determining household participation in domestic waste management in various ways. Domestic solid waste management methods have been discussed in relation to the need for EE. This discussion concludes that higher levels of environmental education are required for the application of very efficient methods such as prevention, re-use and recycling, than is required for less desirable methods such as dumping and open burning. This has useful implications of the planning of domestic waste management.

This chapter has also discussed the status of domestic waste management in South Africa. Solid waste generation in South Africa turns out to be higher than current levels of waste processing. The government shows strong commitments to domestic waste management, but certain instances, such as the case of the plastic bags, reveal that there is a need for institutional strengthening to enhance a strong implementation capacity. There is also a need for asserting more efforts to improve the distribution of waste management services in most cities, which hitherto seems to be biased in favour of the inner core of urban centres.

Chapter 3 introduces the research methods used in the study, giving a brief overview of quantitative research as applied in this study. The research design, data collection and method of analysis are also presented. 


\section{CHAPTER 3}

\section{EMPIRICAL INVESTIGATION OF HOUSEHOLD PARTICIPATION IN DOMESTIC WASTE MANAGEMENT}

\subsection{INTRODUCTION}

In Chapter 2, the theoretical perspectives of household participation in domestic waste disposal and recycling were discussed. The various solid waste management methods were presented. The role of environmental education in enhancing domestic solid waste management was also presented. This was followed by a discussion of the status of domestic waste management in South Africa, particularly in the Tshwane Metropolitan Area (TMA).

This chapter gives an overview of quantitative research in general, methods of gathering data in quantitative research and the purpose of quantitative research in this study. The chapter also gives a detailed description of quantitative research methods as applied in this study. This is followed by a discussion of the research design, which is presented along with a description of the study location, questionnaire design, selection of sites and sample households, limitations of the study, data collection and methods of data analysis used in this study. A brief description of the characteristics of the data used in the analysis is then presented, followed by a summary. 


\subsection{QUANTITATIVE RESEARCH: AN OVERVIEW}

Quantitative research is one of the research approaches used in empirical investigations. It is defined differently by different authors (Leedy, 1993; Bless and Higson-Smith, 1995). Unlike qualitative research, quantitative research involves the collection, analysis and interpretation of numeric data, collected through experiments or surveys, or through interviews using structured or unstructured questionnaires (Leedy, 1993). For the purpose of this study, this definition is adopted as a working definition; that is, the collection, analysis and interpretation of quantitative data using structured household questionnaires.

Data in quantitative research are measurable and can be acquired by various methods, or collected from various primary and secondary sources (Poate \& Daplyn, 1993: 30-55). Primary data is data generated for the first time by the researcher through field measurements, surveys or various kinds of interviews (Poate \& Daplyn, 1993: 30-55). Secondary data is data that has been collected for some other purposes but is suitable and is available for the purpose of the research being conducted. Like primary data, secondary data can be both quantitative and qualitative. Quantitative data from secondary sources include, for instance, numeric data from statistical bureaus, census offices, business data bases and so on (Cresswell, 1994). For empirical research and analysis, data is usually collected from primary sources through surveys or field measurements, or through interviews conducted using structured or unstructured questionnaires (Cresswell, 1994). This study utilises 
primary data collected through surveys and interviews using structured questionnaires.

Interview questionnaires may contain open-ended or closed questions, leading questions, multiple questions, ambiguous questions, probing questions, sensitive topics, etc (Poate \& Daplyn, 1993: 30-55). Each of these sets of questions requires specific skills of the researcher or his/her enumerator to ensure that responses given by the informants to his questions are unbiased (De Vos, et al., 1998). In this study, the data is collected from households selected randomly in pre-selected suburbs (Mamelodi, Waterkloof, Lynnwood and Sunnyside) in the Tshwane Metropolitan Area (TMA).

The data collected in quantitative research may be cross-sectional, time series or pooled (Bryman, 1988; Poate \& Daplyn, 1993). Cross-sectional data is data that is collected only once. For instance, the population of South Africa in a given year (population census), or the quantity of domestic solid waste generated in TMA in a given year. Time series data is data that is collected several times over a given time period, at designated time intervals, focussing on the same sample and the same qualities or variables each time. For instance, the monthly amounts of domestic solid waste generated by a given household during a year or over several years. For the purpose of this study, a cross-sectional data is collected through household interviews; that is, collected only once in May 2004. The interviews utilize structured questionnaires which comprise closed-ended questions for the most part, with open- 
ended questions on sensitive issues such as income and wealth, as well as on opinions and suggestions regarding the current domestic waste situation in TMA, which require focused discussion.

\subsubsection{The Purpose of the Quantitative Research}

The purpose of quantitative research is to explain the causes of relationships and as far as possible quantify them in terms of well defined units (Poate \& Daplyn, 1993: 143-170). Because the data used in quantitative analysis is usually taken from a representative sample, it is possible to generalize the findings of quantitative research to the whole population from which the sample is drawn (Bless \& Higson-Smith, 1995). Quantitative research is undertaken where it is possible to assign proxies to variables and to measure those proxies, e.g. in terms of percentages, or any other standard defined units that can be interpreted by the researcher.

The purpose of the quantitative research in this study is to investigate the participation of households in domestic waste disposal and recycling from an environmental education perspective. The analysis is used to substantiate the view that participation in domestic waste disposal and recycling varies with the level of environmental education (Balantyne and Oelofse, 1989: 25-32; Garner, 2001: 43-44). That is, lack of participation in domestic waste disposal and recycling can be primarily due to lack of environmental education, but may be also due to other social and economic factors. For instance, residents of fairly wealthy settlements in Tshwane, such as Waterkloof 
and Lynnwood, are likely to be in a position to participate in private waste collection schemes that require monthly contribution. From an environmental education perspective, one would also expect high literacy rates in these areas, compared to spontaneous settlements in the city outskirts and relatively poor townships. Should this higher level of education imply a higher knowledge of environmental issues (which this study will substantiate), one would expect a higher willingness and incentive for proper domestic waste management. Also, access to media equipments such as radio and television, through which public environmental education programmes and relevant debates are transmitted, may differ across different settlements.

The quantitative research uses these background assumptions to randomly select and analyse a sample of households from four different suburbs in TMA. These households were stratified on the basis of diverging suburb locations, income levels and education, and analysed to assess differences in level of household participation in domestic waste management and recycling, as applied in Poate and Daplyn (1993: 143-144).

\subsubsection{Sampling Procedure in Quantitative Research}

Quantitative research involves objective measurements, which may include testing of hypothesis to predict human behaviours or explain certain phenomenon. The explanation of phenomenon or testing of hypothesis requires the utilization of empirical data, collected directly by the researcher or using an existing secondary 
data (see Section 3.2). This subsection will focus mainly on primary data collection, which is the method applied in this study.

Once the study objectives are well established and the phenomenon to be explained or hypothesis to be tested is well defined, the sample size and methods of data collection become the next relevant issues. The choice of the study location is determined by several factors, including the topic, availability of resources and purpose of the study. The sample size is largely determined by the choice of analytical methods. Generally, the larger the sample size the stronger the inference that can be made from it and generalized to the study population (Poate and Daplyn, 1993: 143145).

Collecting data through interviews require designing of a questionnaire through which the data is collected. The basic aim of data collection is to try to ensure that the information collected for analysis is as near as possible to reality (Poate and Daplyn, 1993:143). After selecting the sample, (which involves standard procedures) the questionnaire facilitates the process of questioning the respondents in a systematic way, recording their responses, and summarizing those responses in ways that enhance the analysis of the responses to generate answers to the questions inherent in the study objectives. At every stage in this process, there is a potential for errors, and the questionnaire design should be a major contributing element to the avoidance or minimization of these errors. Also, not all forms of enquiries are appropriate for questionnaires. Inquires such as informal exploratory surveys and detailed follow-up 
to specific cases do not require questionnaires, since the purpose is to permit an open-ended discussion, though they may need checklists to guide such discussions (Poate and Daplyn, 1993: 143-170).

With a questionnaire, very different classes of information may lend themselves to different styles of enquiry. Simple factual statements of waste generation (quantities), method of disposal of different types of domestic solid waste, types and quantities of solid wastes recycled, etc, can all be obtained by questionnaires, and as such a questionnaire is used to collect the data that is utilized in this study.

\subsection{RESEARCH DESIGN}

This section deals with the design of the empirical research. The section briefly introduces the study location and highlights its biophysical attributes. It discusses the site selection and the selection of the sample households. The limitations of the study are highlighted, followed by discussion of the data collection process.

\subsubsection{Location of the Study Area}

The Tshwane Metropolitan Area (TMA) comprises Tshwane (Pretoria Town) and its surrounding Townships, such as Mamelodi, Shoshangove and Atteridgeville, which

together occupy an area of over $900 \mathrm{~km}^{2}$ (State of the Environment Report, 2002). TMA is located in Gauteng Province, $45 \mathrm{~km}$ north of Johannesburg in the North 
Central part of South Africa (Figure 2). The area is conducive for urban settlement with an altitude that ranges up to 1,370 meters above sea level. Average daily temperatures fluctuate between $15-28{ }^{\circ} \mathrm{C}$ in summer and between $6-23{ }^{\circ} \mathrm{C}$ in winter (State of the Environment Report, 2002). In winter (April to September), frost occurs in some parts of Tshwane, and in summer (October to March), the days can be as hot as $28^{\circ} \mathrm{C}$ on certain occasions.

The population of the TMA stands at about 2 million people in 2001 (Statistics South Africa, 2001). This high figure is both due to natural growth (high birth rates) and rapid rural-urban migration from nearby townships as well as from distant homelands (Statistics South Africa, 2001). The population of TMA is very diverse, ranging from the very high income classes in the inner city (Waterkloof, Lynnwood, etc.), through the middle income categories in areas such as Sunnyside, to the relatively poorer inhabitants in the city outskirts and surrounding townships (Statistics South Africa, 2001). Due to these differences in wealth and settlement patterns, the situation of domestic waste management in these settlements differs. In order to have a balanced overview of household participation in domestic waste disposal and recycling, it is imperative for the sampling to include households both in the inner city and in the outskirts. Details of the age, gender and settlement distribution of the population of Tshwane can be obtained on the following website: http://www.statssa gov.za/census01/html/ C2001SumReport.asp [accessed 27 June, 2005]). 


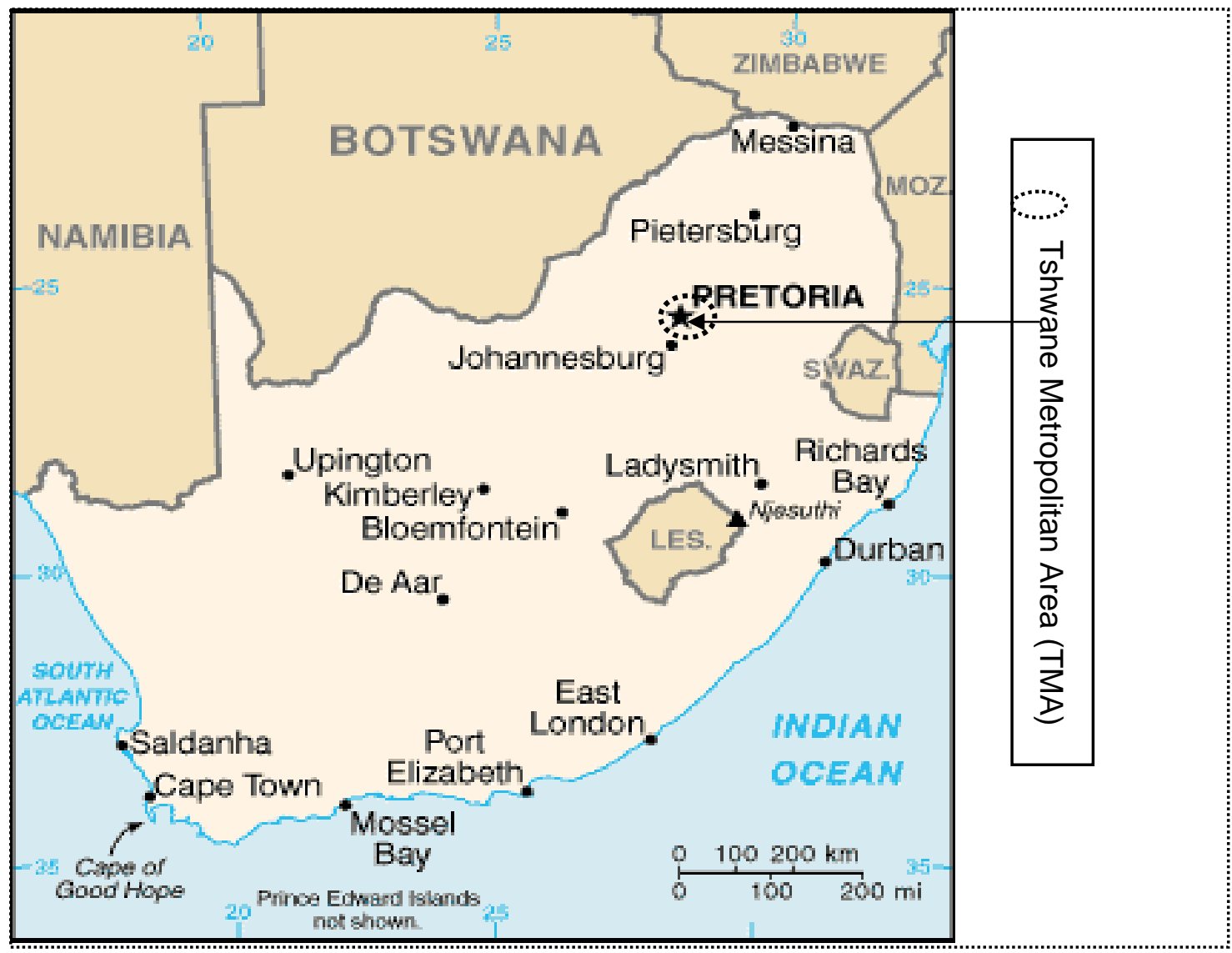

Figure 2: Location of the Tshwane Metropolitan Area

Source: The World Book of Facts, 2003 (http://www.cia.gov./cia/publications/factbook/geos/sf.html)

\subsubsection{Questionnaire Design}

Questionnaire design generally entails the exercise of drawing up a list of question topics from the theoretical section of the study which then forms the subheadings in the questionnaire. It also entails the exercise of phrasing the specific information required for each section of the questionnaire and listing this specific information in a logical and sequential order, following either a chronological or sequential pattern 
(Poate and Daplyn, 1993: 143-170). A decision is then taken on how to record the responses to each question, and the questionnaire is then developed into a pilot draft questionnaire. The draft is then pre-tested in a pilot test or pilot survey. Many items are reviewed after the pilot survey, and the questions are revised as well to get a final questionnaire that is then ready for the survey. In some cases, questions are coded to facilitate easy processing. This procedure was adopted for designing the questionnaires used in this study, and a sample of the questionnaires used in the study is attached in Annexure 2.

\subsubsection{Site selection}

A key criterion for selecting sites was the representation of the various types of domestic waste management scenarios in TMA. A purposeful selection of suburbs was imperative so as to include the various typologies of suburbs in Tshwane. Proximity of the suburbs to the resident of the researcher was also a secondary criterion, as well as diversity of households among the selected sites. This led to the purposeful selection of four suburbs, namely Lynnwood, Waterkloof, Sunnyside and Mamelodi, which represent the diversity of suburbs in terms of education, wealth and coverage with waste management services.

Lynnwood is an upper middle income area in the east of Tshwane (Pretoria East), occupied mainly by civil servants and relatively well-to-do middle income workers. Residents in Sunnyside generally belong to the lower middle income class compared 
to residents of Waterkloof and Lynnwood. Sunnyside is relatively clean, well served with waste management facilities in some parts.

Mamelodi is a typical township with well arranged streets and modern houses. The township is widely expanding into the scattered informal settlements, especially areas occupied by new migrants arriving from rural areas. The township is located just outside Tshwane (outside Pretoria East) and is not well serviced with waste management facilities. There are central garbage containers located in some parts, which are often overfilled with all sorts of garbage (organic, plastic, metal scraps, etc.), with hardly any sorting. These four diverse sites make it possible to select households that are representative of the waste management situation in Tshwane.

\subsubsection{Household Sampling}

Sampling is the selection of a representative part of the population from which the data for an empirical analysis is drawn (Stoker, 1989:100; Bless and Higson-Smith, 1995). In most empirical research, it is impracticable or uneconomical to collect information from the entire population of interest, e.g. a whole country, or a city of two million residents. Therefore the purpose of sampling is to economise on the use of resources in gathering information, by selecting a subset of the population (a sample) from which information can be acquired to serve the same purpose (Poate and Daplyn, 1993: 31). For the sample to be representative, it is advisable to collect it through random sampling methods. 
For this study, the Simple Random Sampling (SRS) method was used. A simple random sampling requires a 'sampling frame', that is, a list of sampling units (households for this study), from which the sample is selected using a random sampling method (Poate and Daplyn, 1993: 53-55). The units (households) listed in the frame must be numbered in a sequence, starting with one as the first item at the head of the list and continuing down to the last item. A table of random numbers is then used to generate a random selection of numbers, and the households corresponding to these numbers in the list are then selected for the survey (Poate and Daplyn, 1993: 53).

To acquire the sampling frame for this study, a list of 160 households was created, comprising 40 households from each of the four suburbs named above (see Section 3.3.3). The selected 160 households were then numbered in sequence to create the sampling frame, from which the 60 households to be interviewed were randomly selected. A table of random numbers was used to generate 60 random numbers, representing the sample size for the survey. The households corresponding to these numbers were then selected from the list of the sampling frame for the interviews.

\subsubsection{Limitations of the Study}

One of the key limitations of the study was the fact that the data collection could not be carried out by the researcher alone; she had to recruit enumerators to assist 
especially in Sunnyside and Mamelodi. This was partly due to time constraints, partly due to security reasons in relatively unsafe areas, and also due to language barrier especially in Mamelodi, where local South African languages are spoken which the researcher could not understand. There was also a difficulty of accessibility of the household members ${ }^{3}$.

Because of this difficulties of accessibility, and sometimes repelling attitudes of some of the selected households, the selected sample size of 60 households could not all be interviewed. Only a total of 46 households could be reached and interviewed, which was still reasonably representative for the analysis. The resulting distribution of the households interviewed entailed 10 households from Lynnwood, 13 households from Sunnyside, 15 households from Mamelodi and 8 households from Waterkloof. Accessibility of respondent households was specifically difficult in the relatively wealthy areas of Lynnwood and Waterkloof, as the residents were hardly available. This difficulty is reflected in the relatively small numbers of respondents covered in theses areas.

\subsubsection{The Interviews}

The data was collected during a two month period covering May and June in 2004. The data collection entailed intensive interviews with the household heads or their closest deputies, using a structured questionnaire which was designed as explained in

\footnotetext{
${ }^{3}$ The occupants of some of the selected household were not available. In some cases, none of the household members was willing to take the interview. This reduced the sample size from the initial target of 60 to 46 households.
} 
Section 3.3.2. The questionnaire was detailed, five pages long, and consisted mainly of close-ended questions that served to gather information on the basic socioeconomic characteristics of the household heads such as age, marital status, household size, education, level of income, environmental awareness, awareness of waste management issues, as well as questions relating to participation in domestic waste disposal and recycling. Some open-ended questions were also included to facilitate oral discussions and assessment of opinions. These conversations between interviewers and interviewees were flexible, and the responses were written down and utilised as background information for the data interpretation. A sample of the questionnaire used for the data collection is attached in Annexure 2.

\subsubsection{Methods of Data Analysis}

The data was analysed using simple exploratory methods such as descriptive and simple statistical analysis (Poate and Daplyn, 1993: 243-275). The descriptive statistics was used to assess the socio-economic profile of the sample households, such as income dynamics, level of education, household demographics, dependency ratios, and so on. This description was necessary to highlight statistical characteristics of the data used in the analysis which is very imperative in quantitative analysis (Poate and Daplyn, 1993), and to form a basis for sample stratification, by income, by level of education and by suburb. 
The statistical analysis enhances the estimation of arithmetic means and percentages to investigate household participation in domestic waste disposal and recycling. Using the descriptive statistics, the households are stratified in various categories of income, education and suburbs, and their responses to various questions on waste management are analysed on simple percentage basis, and standard deviations to assess the variation of responses across the sample.

To investigate the level of awareness of households in the TMA about proper domestic waste disposal and recycling, the questionnaire entailed questions that sought information about awareness, which are analysed by simple stratification (Poate and Daplyn, 1993).

To assess the level of household participation in waste management, relevant questions on participation were developed in the questionnaires, which are analysed by suburbs, income and level of education. It may generally be expected that some relationship exist between level of education and knowledge of the environment (environmental education), though this may not always necessarily be the case (Garner, 2001). Also, the data is analysed by income categories due to the hypothesised positive correlation between income and access to the media (TV, radio) and hence access to more public information regarding the environment (Garner, 2001: 43-44). Similar assumptions are made about the suburbs and the inner city, which leads to the participation analysis focussing on suburb, level of education and income. 
The level of participation in waste management activities (recycling and disposal) are assessed on the basis of four principal questions focusing on the following critical areas:

i. Participation in a waste management scheme of any sort, public or private;

ii. Payment of any kind of waste management fee;

iii. Sorting of recyclable domestic waste of any sort (paper, plastic, metal scraps, etc.) either willingly or paid for; and

iv. Whether or not the respondent intends to continue sorting domestic waste, or will start domestic waste sorting if the household is not already doing so.

The results obtained to these questions are analysed and presented in Chapter 4 .

\subsection{DATA CHARACTERISTICS}

As indicated in Table 1, the sample consists of 46 households, with respondents of ages between 23 and 68 years, with an average of 38 years, with a fairly even distribution as indicated by a standard deviation 9.8. Household sizes are relatively small across the sample, with an average around 5 persons per household and a maximum of 9. An unusual one person per household occurs within the sample, but only once as this is very rear in South Africa. Over $50 \%$ of the sample population is children, with an average of over two children per family, and an unusually high figure of seven children per family that occurred only once. 
Twenty-one percent of the sample population comprises old people, which is relatively fairly distributed across the sample. This relatively large number of children and old people among the inhabitants of the sample household leads to an average dependency ratio

Table 1: Basic Characteristics of Sample Households

\begin{tabular}{|l|c|c|c|c|}
\hline \multirow{2}{*}{ Variable } & \multicolumn{4}{|l|}{ Household characteristics of respondents (N = 46) } \\
\cline { 2 - 5 } & Minimum & Mean & Maximum & $\begin{array}{l}\text { Standard } \\
\text { Deviation }\end{array}$ \\
\hline Age of respond (years) & 23 & 38 & 68 & 9.8 \\
\hline Size household (people) & 1 & 4.7 & 11 & 1.5 \\
\hline Total number of children & 0 & 2.4 & 6 & 1.4 \\
\hline Total number of old people & 0 & 1 & 3 & 1 \\
\hline Dependency ratio & 0 & 3.6 & 5.5 & -- \\
\hline
\end{tabular}

Source: Author, Field Survey, 2004

of about 3.6, with a maximum of about 5.5. This gives an indication of the relatively high economic pressure on the working population in TMA, in terms of responsibility for the livelihoods of unemployed relatives or of non-working age.

\subsubsection{Educational Categories of Respondents}

As indicated in Annex 3, nearly all the respondents have some form of education. That is, over $90 \%$ of the respondents have some form of formal education, ranging from primary to university level. Nearly $40 \%$ of the respondents acquired university education. Nearly $30 \%$ of the respondent acquired education above secondary school. That is $19 \%$ went to training colleges and $10 \%$ to technical institutes. These figures greatly reflect the relative high literacy rate in urban centres in South Africa, especially 
in the TMA. About $19 \%$ of the respondents only attained secondary school education, only $2 \%$ attended primary schools, while $4 \%$ attained various forms of informal education, categorised as 'others'. Of the entire sample, only about $2 \%$ of household heads had no form of education at all. Finally, another $4 \%$ of the sample failed to respond to this question, categorised 'missing' responses.

\subsubsection{Household Characteristic by Education Level}

The age distribution of the respondents across education category (Annexure 4) indicates that there is a relationship between age and education. That is, the age categories with little or no education mainly comprise old people between the ages of 62 and 68 years. The age distribution of the university graduates is skewed around a mean of 41 years, while those who acquired technical education or attended training colleges are mainly within the youthful ages of about 34 years (Annexure 4).

Household sizes seem to decrease with level of education, with the largest household sizes, (6 to 9 people) in the categories with no formal education or no tertiary education. There are no significant variations of household sizes across the various categories of tertiary education. Similarly, the number of children per household is highest in the category of respondents that acquired only primary education ( 5 children per household). Among the category of respondents with university education, the number of children per household is lowest, with an average of 0.32 
child per family, which is however very skewed in distribution, as indicated by a standard deviation of 0.82 .

The proportion of old people are relatively low in the sample, less than 2 old people per household across all categories, except the non-educated and the primary school categories. Dependency ratios are relatively high, ranging from 4.5 persons per worker, to the lowest of 2.5 persons per worker (Annexure 4). The highest dependency rations are observed in the categories of highly educated respondents (4 persons per worker). This is however not consistent, since about 4.5 persons per worker on the average is found in the category of respondents with only primary school education.

\subsubsection{Sources of Income and Livelihood}

As indicated in Annex 5, nearly all the respondents are involved in some form of income generating activity. Over $60 \%$ of the respondents are either self-employed or employed by some institution. About $19 \%$ of the sample respondents are selfemployed in one kind of activity or the other. Teachers and lecturers comprise about 14\%. About $10 \%$ are medical practitioners while $8 \%$ are researchers. Business executives accounts for about $10 \%$, involved in one kind of business or the other. The remaining occupational categories of the respondents are security guards (10\%), sales persons (8\%), drivers (6\%), auditors (2\%), lawyers (2\%) and secretarial workers (2\%). About $4 \%$ of the respondents are unemployed while $2 \%$ did not respond to this 
question (categorised as 'no response'). These diverse categories of employment may be indicative of the relative availability of employment opportunities in TMA compared to the homelands, which is one of the crucial factors that make it an attractive destination for rural-urban migrants.

\subsubsection{Household Characteristics by Wealth and Suburb}

The age distribution of the sample respondents does not show much variation across the different suburbs (Annexure 7). Respondent from Lynnwood exhibit an average age of 42 years, in Sunnyside 34 years, 38 years in Mamelodi and 42 years in Waterkloof, with mean of 37 years for the entire sample. There are 2 children per household in all suburbs except in Mamelodi where the figure is slightly higher (an average of 3 children per household) and lower in Waterkloof, with a single child per household on the average. Old people are virtually absent in the sample households from Lynnwood and Waterkloof, while Mamelodi and Sunnyside each has about one old person per household on the average (Annexure 7). Dependency ratios across suburbs showed significant variations across suburbs. Mamelodi exhibits the highest dependency ratios of about 5 persons per worker, followed by Lynnwood ( 4 persons per worker), Waterkloof (3 persons per worker), and Sunnyside has the lowest dependency ratio of 2.5 persons per worker (Annexure 7).

The sample was also stratified by wealth classes based on income categorisations constructed in the questionnaires, and the basic socio-economic household 
characteristics assessed in terms of variations across these wealth classes (Annexure 7). The average age distribution remains constant at about 40 years on the average among the wealthy and middle class households, while most of the poorer households seem to have relatively younger household heads of about 34 years on the average. The middle class and poorer household classes have more older person per household on the average than the wealthier households. Dependency ratios across the wealthy class, middle class and poorer class do not show much variation.

\subsection{Summary}

This chapter has given a general introduction of quantitative research methods, and has established its purpose and relevance for this study. The relevant methodological issues such as site selection, household sampling, questionnaire design and data collection have been discussed in detail. The research design (including criteria for selecting sites and respondent households) and questionnaires used to explore household participation in domestic waste disposal and recycling have been discussed. The chapter has also described the process of data collections, analytical methods and the limitation of the study. As required in quantitative analysis (Poate and Daplyn, 1993: 243-275), the descriptive statistics of data collected for the analysis has also been presented (Section 3.4, with details in Annexure 3 to 7 ).

The descriptive statistics show that the selected households are very diverse. Such a diversity in sample is required to give a comprehensive picture of household 
participation in domestic waste disposal and recycling in TMA. There is a significant variation in age, household size, composition of household as well as dependency ratios, educational categories and level of education of household heads. These attributes also vary across suburbs and across various income classes, thus forming a solid data base for exploring household participation in domestic waste management across households in study area. 


\section{CHAPTER 4}

\section{RESULTS OF THE EMPIRICAL ANALYSIS}

\section{AND DISCUSSION}

\subsection{INTRODUCTION}

Chapter 3 has introduced the research methods and established its purpose and relevance for this study. Relevant methodological issues such as site selection, household sampling, questionnaire design and the data collection process were discussed in detail. Chapter 3 has also presented a detailed descriptive statistics of the data that will be used for the analysis of household participation in domestic waste disposal and recycling in TMA.

In this chapter (Chapter 4), the results of the analysis of household participation in domestic waste disposal and recycling in TMA are presented. The results are reported in four main sections. The first section presents the results of the investigation of household awareness in domestic waste management in TMA. The second section presents the results of the investigation of household participation in domestic waste disposal and recycling, focusing on location, income, and level of education. The third section presents an analysis of the factors affecting household participation in domestic waste management and recycling, including institutional factors. The fourth 
section discusses the results of the analysis from an environmental education perspective, followed by a summary.

\subsection{AWARENESS IN DOMESTIC WASTE MANAGEMENT IN TMA}

In order to explore the level of awareness of the respondent households about the relevance of waste management, a general question was designed about the importance of waste sorting (Annexure 2). To the question 'what do you think is the importance of waste sorting?' the responses obtained are analysed and the results presented in Figure 3. From the responses, it is clear that people have different perceptions and opinions about waste sorting and recycling and that the general level of awareness is relatively low. About $23 \%$ of the respondents are of the opinion that there is no relationship between waste sorting and the environment.

About $32 \%$ of the respondents are of the opinion that sorting of domestic waste reduces the volume of waste that is to be disposed of, and hence lessens the cost and burden of waste disposal. $25 \%$ are of the opinion that sorting is useful, though they 


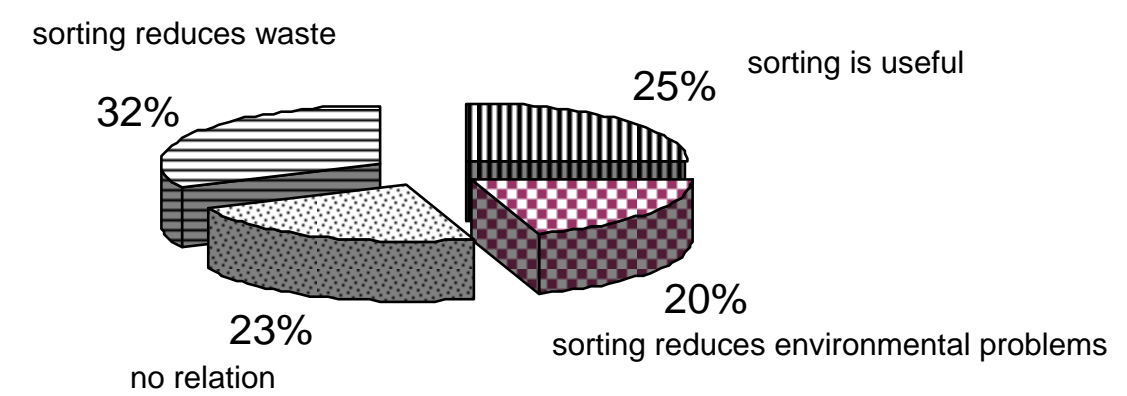

Figure 3: Opinions on the Relevance of Waste Sorting

Source: Author, Field Data, 2004

could hardly elaborate as to how sorting of waste relates to environmental problems. Only $20 \%$ of the entire sample is of the opinion that there is a direct linkage between proper waste sorting and the quality of the environment. That is, that domestic waste sorting enhances recycling of valuable materials, which relieves pressure on scarce raw materials and reduces environmental problems. These figures are very encouraging, and create an important need to see how these responses vary across suburbs, wealth classes and varying levels of education. The relatively low level of public awareness of the relevance of waste sorting may also have a direct bearing on peoples' participation in waste management. The findings may be indicative of a strong need to increase awareness raising efforts, since it may have important implications for public participation in waste management. 


\subsection{HOUSEHOLD PARTICIPATION IN DOMESTIC WASTE DISPOSAL AND RECYCLING IN TMA}

Household participation in domestic waste disposal and recycling is presented in three subsections, focusing on the variation of household location or study suburb (Lynnwood, Mamelodi, Waterkloof and Sunnyside), income classes which depict access to EE facilities such as the media (TV, News Papers, etc), and level of education which may depict level of environmental awareness and education.

\subsubsection{Domestic Waste Disposal and Recycling by Suburb (Lynnwood, Mamelodi, Waterkloof and Sunnyside)}

As highlighted in Table 2, the highest level of participation in domestic waste disposal is observed in Waterkloof and Lynnwood, where $100 \%$ of the sample households participate in, or are served by, some form of waste disposal system, mainly via household garbage containers. About $69 \%$ of the sample households from Sunnyside participate in some form of waste disposal system, while the figure drops to $46 \%$ in Mamelodi, which is a township suburb around Tshwane East. Overall, $74 \%$ of the sample households in TMA participate in one form of disposal system or the other. Though these figures are encouraging, there is still a big room for improvement, given the fact that they are representative of the general extent of low coverage and outreach of waste management facilities in TMA. 
Table 2: $\quad$ Participation in Waste Management by Suburb

\begin{tabular}{|c|c|c|c|c|c|c|c|c|c|c|c|}
\hline \multirow{2}{*}{\multicolumn{2}{|c|}{$\begin{array}{l}\text { Area of Participa- } \\
\text { tion/Responses }\end{array}$}} & \multicolumn{8}{|c|}{ Household Location (Suburb) } & \multirow{2}{*}{\multicolumn{2}{|c|}{ Sample }} \\
\hline & & \multicolumn{2}{|c|}{ Lynnwood } & \multicolumn{2}{|c|}{ Sunnyside } & \multicolumn{2}{|c|}{ Mamelodi } & \multicolumn{2}{|c|}{ Waterkloof } & & \\
\hline Area & Response & No. & $\%$ & No. & $\%$ & No. & $\%$ & No. & $\%$ & No. & $\%$ \\
\hline 1 & $\begin{array}{l}\text { Yes } \\
\text { No }\end{array}$ & $\begin{array}{l}10 \\
0\end{array}$ & $\begin{array}{l}100 \\
0\end{array}$ & \begin{tabular}{|l}
9 \\
4
\end{tabular} & $\begin{array}{l}69 \\
31\end{array}$ & $\begin{array}{l}7 \\
8\end{array}$ & $\begin{array}{l}46 \\
54\end{array}$ & $\begin{array}{l}8 \\
0\end{array}$ & $\begin{array}{l}100 \\
0\end{array}$ & $\begin{array}{l}34 \\
12\end{array}$ & $\begin{array}{l}74 \\
26\end{array}$ \\
\hline 2 & $\begin{array}{l}\text { Yes } \\
\text { No }\end{array}$ & $\begin{array}{l}10 \\
0\end{array}$ & $\begin{array}{l}100 \\
0\end{array}$ & $\begin{array}{l}7 \\
6 \\
\end{array}$ & $\begin{array}{l}54 \\
46\end{array}$ & $\begin{array}{l}0 \\
15\end{array}$ & $\begin{array}{l}0 \\
100\end{array}$ & $\begin{array}{l}8 \\
0\end{array}$ & $\begin{array}{l}100 \\
0\end{array}$ & $\begin{array}{l}25 \\
21\end{array}$ & $\begin{array}{l}53 \\
47\end{array}$ \\
\hline 3 & $\begin{array}{l}\text { Yes } \\
\text { No }\end{array}$ & $\begin{array}{l}3 \\
7 \\
\end{array}$ & $\begin{array}{l}30 \\
70 \\
\end{array}$ & \begin{tabular}{|l|}
2 \\
11 \\
\end{tabular} & $\begin{array}{l}15 \\
85 \\
\end{array}$ & $\begin{array}{l}0 \\
15 \\
\end{array}$ & $\begin{array}{l}0 \\
100 \\
\end{array}$ & $\begin{array}{l}4 \\
4 \\
\end{array}$ & $\begin{array}{l}50 \\
50 \\
\end{array}$ & $\begin{array}{l}9 \\
37 \\
\end{array}$ & $\begin{array}{l}20 \\
80 \\
\end{array}$ \\
\hline 4 & $\begin{array}{l}\text { Yes } \\
\text { No }\end{array}$ & $\begin{array}{l}4 \\
6 \\
\end{array}$ & $\begin{array}{l}40 \\
60 \\
\end{array}$ & \begin{tabular}{|l|}
2 \\
11 \\
\end{tabular} & $\begin{array}{l}15 \\
85\end{array}$ & $\begin{array}{l}0 \\
15\end{array}$ & $\begin{array}{l}0 \\
100 \\
\end{array}$ & $\begin{array}{l}8 \\
0 \\
\end{array}$ & $\begin{array}{l}100 \\
0\end{array}$ & $\begin{array}{l}13 \\
33 \\
\end{array}$ & $\begin{array}{l}28 \\
72 \\
\end{array}$ \\
\hline & & \multicolumn{2}{|c|}{$\mathrm{n}=10$} & \multicolumn{2}{|c|}{$\mathrm{n}=13$} & \multicolumn{2}{|c|}{$\mathrm{n}=15$} & \multicolumn{2}{|c|}{$\mathrm{n}=8$} & \multicolumn{2}{|c|}{$\mathrm{N}=46$} \\
\hline \multicolumn{12}{|c|}{ Definitions } \\
\hline 1 & \multicolumn{11}{|c|}{$\begin{array}{l}\text { Does your household participate in waste disposal system, e.g. via containers } \\
\text { public/private? }\end{array}$} \\
\hline 2 & \multicolumn{11}{|c|}{ Are you currently paying for your garbage disposal system? } \\
\hline 3 & \multicolumn{11}{|c|}{$\begin{array}{l}\text { Does your household sort garbage e.g. separate scrap metals, plastics, papers, } \\
\text { organic, etc.? }\end{array}$} \\
\hline 4 & \multicolumn{11}{|c|}{ Will you continue to sort your garbage in future, or do you intend to start sorting? } \\
\hline
\end{tabular}

Source: Author, Field Data, 2004

The level of participation observed in the various parts of TMA is also reflected in the current level of payment for the services. In Waterkloof and Lynnwood, all residents claimed to be paying for waste disposal services, a figure that drops to $54 \%$ in the relatively less orderly settlement of Sunnyside. In Mamelodi, none of the respondents is paying for waste management services, which could imply that either the area is not well covered by waste management services, or that people are not prepared to pay for the services due to lack of finance resources, or lack of adequate environmental education to make them realize the need to participate in the services. Overall, only about $53 \%$ of the entire sample households in TMA are currently paying for waste management services, which is a relatively low figure. 
The level of household participation in garbage sorting is alarmingly low in the entire TMA (Table 2). The highest level of participation in sorting (50\%) is observed among residents in Waterkloof, where some households are engaged in sorting out plastic, metal scrap, paper and organic matter. In Lynnwood, only about $30 \%$ of the sample households sort their garbage while the figure drops to $15 \%$ in Sunnyside, and to $0 \%$ in Mamelodi. Overall, only 9 out of the 46 respondent households (20\%) in the entire sample sort their garbage. This low participation in garbage sorting in the entire TMA could allude to a low level of awareness of environmental issues and low environmental education (formal or informal), which may culminate into an apathy towards waste sorting. Under the prevailing circumstances, and the current stand of environmental education knowledge, only about $28 \%$ of households in TMA intend to continue sorting in future or take up to sorting (Table 2), mainly residents in Waterkloof and to a lesser extend in Lynnwood.

\subsubsection{Waste Recycling and Disposal by Income and Wealth}

Participation in domestic waste recycling and disposal also varies across the income classes. The income categories were constructed by scoring, using a set of criteria that reflects the current situation in South Africa ${ }^{4}$. Based on these categories, the results indicate that $100 \%$ of the wealthy households participate in waste recycling and disposal, and are served by some form of waste disposal systems (Table 3). Only

\footnotetext{
${ }^{4}$ The criteria for classifying the households was quite arbitrary, and entailed the possession of certain amenities such as a vehicle and TV, and the annual income level. Households with annual incomes of R50,000.00 and above were classified as wealthy, between R10,000.00 and R50,000.00 as middle class, and below R10,000.00 were classified as poor. Based on these criteria, the enumerator simply assigned the respondent to one of the three wealth classes.
} 
about $79 \%$ middle income households participate in, or are served by a formal domestic waste disposal system, while only $27 \%$ of the poor category participate in a formal waste disposal system. Similarly, all the households in the wealthy category are currently paying for waste management services. Only $47 \%$ of middle income households pay for waste disposal services while none of the households in the poor category currently pay for waste disposal services. This is a very important observation as it calls for a need to thoroughly understand whether there are any discernable linkages between low participation of poorer households in waste disposal programme, their failure to pay for services and the limited coverage of poorer households with domestic waste management facilities.

As with participation in waste disposal and payment of domestic waste management

Table 3: Participation in Waste Management by Income and Wealth

\begin{tabular}{|c|c|c|c|c|c|c|c|c|c|}
\hline \multirow{2}{*}{\multicolumn{2}{|c|}{$\begin{array}{l}\text { Area of } \\
\text { Participation } \\
\text { I Responses }\end{array}$}} & \multicolumn{6}{|c|}{ Income categories } & \multirow{2}{*}{\multicolumn{2}{|c|}{ Sample }} \\
\hline & & \multicolumn{2}{|c|}{ Wealthy } & \multicolumn{2}{|c|}{ Middle Class } & \multicolumn{2}{|c|}{ Poor } & & \\
\hline Area & Response & No. & $\%$ & No. & $\%$ & No. & $\%$ & No. & $\%$ \\
\hline 1 & $\begin{array}{l}\text { Yes } \\
\text { No }\end{array}$ & $\begin{array}{l}16 \\
0\end{array}$ & $\begin{array}{l}100 \\
0\end{array}$ & $\begin{array}{l}15 \\
4\end{array}$ & $\begin{array}{l}79 \\
21\end{array}$ & $\begin{array}{l}3 \\
8\end{array}$ & $\begin{array}{l}27 \\
73\end{array}$ & $\begin{array}{l}34 \\
12\end{array}$ & $\begin{array}{l}74 \\
26\end{array}$ \\
\hline 2 & $\begin{array}{l}\text { Yes } \\
\text { No }\end{array}$ & $\begin{array}{l}16 \\
0\end{array}$ & $\begin{array}{l}100 \\
0\end{array}$ & $\begin{array}{l}99 \\
10\end{array}$ & $\begin{array}{l}47 \\
53\end{array}$ & $\begin{array}{l}0 \\
11\end{array}$ & $\begin{array}{l}0 \\
100\end{array}$ & $\begin{array}{l}25 \\
21\end{array}$ & $\begin{array}{l}53 \\
47\end{array}$ \\
\hline 3 & $\begin{array}{l}\text { Yes } \\
\text { No }\end{array}$ & $\begin{array}{l}7 \\
9 \\
\end{array}$ & $\begin{array}{l}44 \\
56 \\
\end{array}$ & $\begin{array}{l}2 \\
17 \\
\end{array}$ & $\begin{array}{l}11 \\
89\end{array}$ & $\begin{array}{l}0 \\
11 \\
\end{array}$ & $\begin{array}{l}0 \\
100 \\
\end{array}$ & $\begin{array}{l}9 \\
37\end{array}$ & $\begin{array}{l}20 \\
80\end{array}$ \\
\hline 4 & $\begin{array}{l}\text { Yes } \\
\text { No }\end{array}$ & $\begin{array}{l}10 \\
6\end{array}$ & $\begin{array}{l}63 \\
37\end{array}$ & $\begin{array}{l}3 \\
16\end{array}$ & $\begin{array}{l}16 \\
84\end{array}$ & $\begin{array}{l}0 \\
11\end{array}$ & $\begin{array}{l}0 \\
100\end{array}$ & $\begin{array}{l}13 \\
33\end{array}$ & $\begin{array}{l}28 \\
72\end{array}$ \\
\hline & & \multicolumn{2}{|c|}{$\mathrm{n}=16$} & \multicolumn{2}{|c|}{$\mathrm{n}=19$} & \multicolumn{2}{|c|}{$\mathrm{n}=11$} & \multicolumn{2}{|c|}{$\mathrm{N}=46$} \\
\hline \multicolumn{10}{|c|}{ Definitions } \\
\hline 1 & \multicolumn{9}{|c|}{ Does your household participate in waste disposal system, e.g. via containers public/private? } \\
\hline 2 & \multicolumn{9}{|c|}{ Are you currently paying for your garbage disposal system? } \\
\hline 3 & \multicolumn{9}{|c|}{ Does your household sort garbage e.g. scrap metals, plastics, papers, organic, etc.? } \\
\hline 4 & \multicolumn{9}{|c|}{ Will you continue to sort your garbage in future/do you intend to start sorting? } \\
\hline
\end{tabular}

Source: Author, Field Data, 2004 
fees, the trends of participation in the sorting of domestic wastes also varies across wealthy, middle class and poor households (Table 3 ). About $44 \%$ of the wealthy households are currently engaged in domestic waste sorting while only $11 \%$ of the middle class households are sorting their domestic waste. None of the poor households is engaged in domestic waste sorting, though $27 \%$ are currently engaged in waste disposal and are served by waste management facilities. While the figures are very disappointing, the future does not seem to hold any promise for significant changes either. Only about $63 \%$ of the wealthy households intend to continue sorting or plan to start sorting. In the middle class category however, only $16 \%$ of the middle class category intend to continue sorting domestic waste or take up to sorting before disposal. None of the poorer households intend to take up to sorting. While the difference between wealthy, middle class and poor in terms of waste management, payment of fees and sorting may be related to affordability, it could also bear on differential access to the media, public environmental campaign programmes as well as other instruments that raise the level of environmental awareness, and hence increase participation in waste management. As the linkages between education, particularly environmental education, and participation of household in domestic waste management remains unclear, the next section investigates participation of different educational categories in waste management and disposal.

\subsubsection{Domestic Waste Disposal and Recycling by Educational Level}

The education categories covered in the interviews (Annexures 3 and 4) were summarised into four main classes for this analysis. That is, those with no education 
at all, those with only primary school education, those with secondary school education, and those with tertiary education. The study hypothesises an existence of a relationship between level of education and knowledge of environmental issues, and hence knowledge of environmental education. The basis for this assertion is that educated people generally have a greater chance of being reached by formal public environmental education (EE) campaign instruments such as the media (TV, radios) since they can understand the language of the broadcast (English or Afrikaans), or through the newspaper. As to whether being reached by these various media really influences peoples attitudes towards the environment, as may be observed through participation in domestic waste management and disposal, will be assessed in this section.

The results (Table 4) indicate a very strong linkage between level of education and participation in domestic waste management and disposal. No one among those with no education is currently participating in any form of domestic waste disposal system (public or private), nor do any of them pay for domestic waste management services. They currently do not recycle anything and do not intend to do so in the near future either (Table 4). This may suggest that most of the non-educated households may not be aware of the positive environmental attributes of proper domestic waste disposal and recycling, and hence they simply do not care. About $67 \%$ of those with primary education participate in some form of formal waste management systems, as is the case with households having secondary and tertiary education, of which $78 \%$ and 76 $\%$ are currently participating in some form of domestic waste management system respectively. 
Table 4: Participation in Waste Management by Educational Level

\begin{tabular}{|c|c|c|c|c|c|c|c|c|c|c|c|}
\hline \multirow{2}{*}{\multicolumn{2}{|c|}{$\begin{array}{l}\text { Area of Participa- } \\
\text { tion / Responses }\end{array}$}} & \multicolumn{10}{|c|}{ Education categories } \\
\hline & & \multicolumn{2}{|c|}{ No Education } & \multicolumn{2}{|c|}{ Primary } & \multicolumn{2}{|c|}{ Secondary } & \multicolumn{2}{|c|}{ Tertiary } & \multicolumn{2}{|c|}{ Sample } \\
\hline Area & Response & No. & $\%$ & No. & $\%$ & No. & $\%$ & No. & $\%$ & No. & $\%$ \\
\hline 1 & $\begin{array}{l}\text { Yes } \\
\text { No }\end{array}$ & $\begin{array}{l}0 \\
1\end{array}$ & $\begin{array}{l}0 \\
100\end{array}$ & $\begin{array}{l}2 \\
1\end{array}$ & $\begin{array}{l}67 \\
33\end{array}$ & $\begin{array}{l}7 \\
2\end{array}$ & $\begin{array}{l}78 \\
22\end{array}$ & $\begin{array}{l}25 \\
8\end{array}$ & $\begin{array}{l}76 \\
24\end{array}$ & $\begin{array}{l}34 \\
12\end{array}$ & $\begin{array}{l}74 \\
26\end{array}$ \\
\hline 2 & $\begin{array}{l}\text { Yes } \\
\text { No }\end{array}$ & $\begin{array}{l}0 \\
1\end{array}$ & $\begin{array}{l}0 \\
100\end{array}$ & $\begin{array}{l}0 \\
3\end{array}$ & $\begin{array}{l}0 \\
100\end{array}$ & $\begin{array}{l}4 \\
5\end{array}$ & $\begin{array}{l}44 \\
56\end{array}$ & $\begin{array}{l}21 \\
12\end{array}$ & $\begin{array}{l}64 \\
36\end{array}$ & $\begin{array}{l}25 \\
21\end{array}$ & $\begin{array}{l}53 \\
47\end{array}$ \\
\hline 3 & $\begin{array}{l}\text { Yes } \\
\text { No }\end{array}$ & $\begin{array}{l}0 \\
1 \\
\end{array}$ & $\begin{array}{l}0 \\
100 \\
\end{array}$ & $\begin{array}{l}0 \\
3 \\
\end{array}$ & $\begin{array}{l}0 \\
100 \\
\end{array}$ & $\begin{array}{l}3 \\
6 \\
\end{array}$ & $\begin{array}{l}33 \\
67 \\
\end{array}$ & $\begin{array}{l}6 \\
27 \\
\end{array}$ & $\begin{array}{l}18 \\
82\end{array}$ & $\begin{array}{l}9 \\
37 \\
\end{array}$ & $\begin{array}{l}20 \\
80 \\
\end{array}$ \\
\hline 4 & $\begin{array}{l}\text { Yes } \\
\text { No }\end{array}$ & $\begin{array}{l}0 \\
1\end{array}$ & $\begin{array}{l}0 \\
100 \\
\end{array}$ & $\begin{array}{l}0 \\
3\end{array}$ & $\begin{array}{l}0 \\
100 \\
\end{array}$ & $\begin{array}{l}3 \\
6 \\
\end{array}$ & $\begin{array}{l}33 \\
67 \\
\end{array}$ & $\begin{array}{l}6 \\
27 \\
\end{array}$ & $\begin{array}{l}18 \\
82\end{array}$ & $\begin{array}{l}13 \\
33\end{array}$ & $\begin{array}{l}28 \\
72 \\
\end{array}$ \\
\hline & & \multicolumn{2}{|c|}{$n=1$} & \multicolumn{2}{|c|}{$n=3$} & \multicolumn{2}{|c|}{$n=9$} & \multicolumn{2}{|c|}{$n=33$} & \multicolumn{2}{|c|}{$N=46$} \\
\hline \multicolumn{12}{|c|}{ Definitions } \\
\hline 1 & \multicolumn{11}{|c|}{ Does your household participate in waste disposal system, e.g. via containers public/private? } \\
\hline 2 & \multicolumn{11}{|c|}{ Are you currently paying for your garbage disposal system? } \\
\hline 3 & \multicolumn{11}{|c|}{ Does your household sort waste? e.g. separate scrap metals, plastics, papers, organic, etc.? } \\
\hline 4 & \multicolumn{11}{|c|}{ Will you continue to sort your garbage in future, or do you intend to start sorting? } \\
\hline
\end{tabular}

Source: Author, Field Data, 2004

Payment of fees for domestic waste disposal services is also not common among households with just primary school education, while up to $44 \%$ of those with secondary school education pay for waste management services. Among those with tertiary education, payment of waste management fees is as high as $64 \%$. The fact that these figures directly improve with increasing level of education categories shows that there is some correlation between level of education and environmental education, calling on the need for more efforts to diversify ways of reaching out to less educated urban communities with environmental education programmes.

Domestic waste sorting for recycling among household with secondary and tertiary education is about $33 \%$ and $18 \%$ respectively, while none of the households with 'no education' or with just primary education is engaged in garbage sorting. This trend also conforms to the above observation and alludes to the need for more emphasis for 
raising environmental awareness and education among lower tiers of society, especially those with low income and little access to education. Under the prevailing circumstances, only about $33 \%$ of those with secondary education and $18 \%$ of those with tertiary education intend to continue with garbage sorting, or take up the practice in future. None of the households with little or no education intend to participate in waste sorting in future (Table 4).

\subsection{FACTORS AFFECTING HOUSEHOLD PARTICIPATION IN DOMESTIC WASTE RECYCLING AND DISPOSAL}

As indicated in Section 4.2 and 4.3, the three primary factors hypothesised to influence household participation in domestic waste disposal and recycling have all proven to have some relationship to the observed trends. Household location (suburb), wealth and income, and education, especially environmental education, all affect household participation in domestic waste sorting, disposal and recycling (Section 4.2 and 4.3). These factors are to a large extent interrelated in the way they influence household participation in domestic waste management.

\subsubsection{Location, Income and Educational Factors}

The highest level of participation in domestic waste disposal and sorting were observed in the inner urban core (Waterkloof and Lynnwood), which was significantly less in Sunnyside and drops to about $46 \%$ in the township of Mamelodi. While 
participation in waste sorting is low in the entire TMA (averaging 20\%), participation in waste sorting is nil in Mamelodi, a township settlement outside Tshwane.

Participation in domestic waste recycling and disposal also varies across the various income categories. All the wealthy households (classified on the basis of income) participate in waste disposal, and a significant proportion further do so in waste sorting. A similar trend is also observed in the middle income category while the proportion participating in the poor category is almost negligible, with no immediate hope of improvement, based on the responses. These observations are largely related to the observed trends by location. Most of the poorer households are located in areas around the city outskirts. While the difference between wealthy, middle class and poor in terms of waste management, payment of fees and sorting may be related to affordability, it could also bear on the differential access to public information services and the media, lack of coverage in public environmental education campaign programmes, as well as other instruments that raise the level of environmental awareness, and hence increase participation in waste management.

The results also strongly conform to hypothesised relationship between level of education and participation in waste management and disposal. Involvement in waste disposal, sorting and payment of domestic waste disposal fees all vary directly with level of education and increases with wealth. This calls attention to the need for more efforts to diversify ways of reaching out to less educated urban communities with environmental education programmes. These groups usually constitute of the poorest 
tiers of community, and are generally more difficult to reach as they usually do not have access to the media and cannot read, and hence they lose out on the benefits of formal EE outreach programmes.

\subsubsection{Institutional Factors}

Among institutional factors are the low levels of household coverage with the provision of waste management facilities, as well as the relatively low level of public awareness on environmental implications of proper waste management. Coverage with waste management facilities is primarily an institutional issue in the context of public service provision, or the provision of support to the private sector to take over the provision of waste management services. While one expects that households would make every effort to participate in domestic waste disposal and recycling, a supply-driven approach is recommended by this study, especially in relatively poorer settlements where coverage is currently very low. For South Africa as a whole, coverage with waste management services seems to be concentrated only within the core urban centres (DEAT, 1999; DEAT, 2000), while the rural settlements and informal settlements are hardly served. The same trend is revealed by this study in the Tshwane Metropolitan Area, where the proportion of coverage in the urban core is $100 \%$, while less than $50 \%$ coverage is observed in the outskirts such as Mamelodi. These findings call for a need to be proactive with the provision of waste management services especially in relatively poorer areas that often have higher numbers of people per household (Annexure 7), and hence higher levels of domestic waste generation. 
The other important factor affecting low participation in waste disposal and recycling that is of great institutional relevance is the relatively low level of environmental awareness. This low level of awareness (Figure 3) also translates into a relatively low level of participation in waste management and recycling, since many households are not informed of the positive environmental implications of the waste management efforts they are expected to make. It is of serious concern that up to $20 \%$ of the sample households, drawn in the TMA, think that there is no relationship between waste disposal/recycling and the environment. For such households, one can conclude that the relatively low participation in waste management and recycling is a direct consequence of ignorance and lack of awareness, all other things remaining equal. In general, people will be willing to participate in waste sorting to enhance recycling only if they are informed of the positive environmental consequences of such efforts.

\subsection{AN ENVIRONMENTAL EDUCATION (EE) PERSPECTIVE}

The implications of these findings for environmental education in South Africa are very clear. Almost across every strata of the analysis, the category with the least participation in domestic waste sorting and disposal was certainly the category with the least level of environmental education. In the analysis by suburb, the low participation of households in Mamelodi in domestic waste management, for instance,

was largely due to low coverage with waste management facilities. However, the 
relatively low level of education in Mamelodi (low level of EE) was also proven to be a relevant factor.

Across the wealth classes it also became evident that the least participation in domestic waste sorting and disposal was among the poorest class. Even though this was partly explained by the inability to pay the charges associated with waste management facilities, it is clear from the descriptive statistics (Annexures 3-5) that only a small proportion of the poor category had any form of education. Again, given the linkage between environmental education and the level of education (Section 4.3.3), it is reasonable to conclude that the low participation of this category in waste management is due to lack of environmental education. The same explanation holds for the observation across the education category, which primarily underscores the need for more efforts to increase environmental education campaigns in order to get people involved in waste management. Thus, the environmental education perspective of domestic waste disposal and recycling is intricately linked to all the other factors that influence household participation in waste management.

\subsection{SUMMARY}

This chapter has presented a detailed discussion of the results of the analysis of household awareness and participation in domestic waste recycling and disposal in TMA. The discussion focused on the state of household awareness in domestic waste management in TMA, participation in domestic waste disposal and recycling, and an investigation of the factors affecting household participation in domestic waste 
management and recycling including household location, income, level of education and institutional factors. These factors are discussed from an environmental education perspective. The next chapter (Chapter 5) gives a summary of the results of the analysis discussed in Chapter 4, and implications thereof, followed by recommendations. 


\section{CHAPTER 5}

\section{SUMMARY OF FINDINGS AND RECOMMENDATIONS}

\subsection{INTRODUCTION}

This chapter provides a summary of the findings of the study especially of the empirical analysis presented in Chapter 4. The implications of these findings for improving domestic waste disposal and recycling in TMA is discussed, followed by detailed recommendations for improving domestic waste management in TMA and in South Africa in general.

\subsection{SUMMARY OF FINDINGS}

In summary, the study concludes that there is a low level of household awareness of environmental education and waste management issues in TMA. This low level of awareness translates into a low level of participation in domestic waste management, such as sorting, recycling and disposal of domestic waste. This low level of participation is related to various factors, among which socio-economic (level of education and wealth or income) and institutional factors. 
Environmental education has a direct bearing on household participation in waste disposal and recycling due to its intricate linkage to general level of education. There is a direct positive relationship between the level of education and knowledge of environmental education issues, and hence a higher incentive to participate in domestic waste management. This intricate linkage between domestic waste management and education is particularly interesting as it articulates the need to focus on environmental education as a means of achieving higher levels of domestic waste management in TMA. Availing waste management services without adequate environmental education may in itself not succeed in ensuring mass participation from the public.

Also, it was observed that wealthier households had a higher level of participation in domestic waste sorting and disposal. This was both because of the location of these households in areas well served by waste management facilities, and because of higher levels of education and hence higher knowledge in EE.

\subsection{RECOMMENDATIONS}

The findings of the study have some very relevant implications for the planning and execution of waste management programmes in TMA, and lead to the following recommendations:

1. The proposition of providing more waste management services especially for poorer households and suburbs is recommended. This will give incentives to people to participate in waste management. This recommendation is strongly emphasised by $37 \%$ of the entire respondents, who are of the opinion that the 
provision of garbage containers and waste separation bags, is a critical constraint to participation in waste management by the masses (Annexure 8).

2. It is recommended that EE programmes be strengthened not only in schools but also in the community settlements using informal outreach methods and programmes, either directly through the state, or indirectly through the activities of NGOs.

3. It is recommended that access to EE be increased to enhance participation. About $46 \%$ of the respondents are of the opinion that low participation in waste management is a direct result of low EE (Annexure 9), as well as a general lack of awareness and information (Annexure 6).

4. It is recommended that EE be used as a mechanism of raising peoples' awareness about the relationship between domestic waste management and the environment.

5. Finally, it is recommended that the existing national environmental framework recognizes the above recommendations and incorporate them into their sanitation and domestic waste management strategies. The current efforts of the Department of Environmental Affairs and Tourism (DEAT), as outlined in the 'White Paper on Integrated Pollution and Waste Management' can form a critical basis for realizing these recommendations. 


\section{REFERENCES}

Almorza, D., Brebbia, C. A., Sale, D. and Popov, V. (eds) 2002. Waste Management and The Environment. WIT Press. Southampton, Boston.

Arendse, L. and Godfrey, L. 2002. Waste Management Indicators for National State of Environment Reporting. Environmental Report, Centre for Scientific and Industrial Research (CSIR), Pretoria.

Balantyne, R. R. and Oelofse, C. G., 1989. Implementing Environmental Education Policy in South African Schools, South African Journal of Education, Vol. 9 (1). Balantyne, R. R. and Packer, J. M.1996. Teaching Learning in Environmental Education: Developing Environmental Concepts. Journal of Environmental Education, Vol. 27 (2): 25-32.

Barlow, N. (1997), Education, Training and Research. In: Eagle, S. and Dechamps, J. (eds) (1997), Environmental Protection: Guides to Information Sources. Bowker Saur, London, Melbourne, Munich.

Baud, I. and Shenk, H. 1994. Solid Waste Management: Modes, Assessments, Appraisals and Linkages in Bangalore. Manohar Publishers, New Delhi.

Beede, D. N. and Bloom, D. E. 1995. The Economics of Municipal Solid Waste. The World Bank Research Observer 10(2): August:113-150.

Blaxter, L. Hughes, C., Tight, M. 1996. How to Research. Buckingham, Open University Press.

Bless, C. and Higson-Smith, C. 1995. Fundamental of Social Research Methods: An African Perspective. Kenwyn: Juta

Bryman, A. 1998. Quantity and Quality in Social Research. London: Unwin Hyman.

Clark, S. 2002. Studio Equilibrium: From Discard Construction Materials: Salvaging Construction Waste. Urban Green File. Vol. 7 (1): 31-33.

Coinstreau, S. J., Gunnerson, C. G., Huls, J. M. and Seldman, N. N. 1984. Recycling from Municipal Refuse: A State of the Art Review and Annotated Bibliography. World Bank Technical Paper No. 30. The World Bank, Washington, D.C.

Coinstreau, S. J. 1987. Solid Waste Recycling: Case Studies in Developing Countries. The World Bank, Washington, D. C. 
Cresswell, J. W. 1994. Research Design: Qualitative and Quantitative Approaches.

Thousand Oaks: Sage Publications.

Day,L.,1998. Wise up on Waste, Envirokids. Vol. 19 (3): 17.

DEAT (Department of Environmental Affairs and Tourism), 1999. State of the

Environment South Africa. Department of Environmental Affairs and Tourism,

Pretoria. Internet: http://www.envolironment.gov.za

DEAT (Department of Environmental Affairs and Tourism), 2000. White Paper on

Integrated Pollution and Waste Management for South Africa. Pretoria, Internet: http://www.gov.za/gazette/whitepaper/2000/20978.pdf

De Vos, A. S., Strydom, H., Fouche, C. B., Poggenpoel, M. and Schurink, E. W. 1998.

Research at Grassroots. A Primer for the Caring Professions. Pretoria: Van Schaik.

Ellis, F. 1998. Peasant Economics: Farm Households and Agrarian Development.

Wye Studies Agricultural and Rural Development. Cambridge University Press, UK.

Frewin, J. 1997. Let's brighten our lives by reducing our waste: World Environment Day. Toktokkie. Vol 18 (3): 12-13.

Garner, G. 2001. Waste Aware - An Attempt to Reduce the Waste Stream through Education and Communication: Words on Waste. Urban Green File Vol. 5 (6): 43-44

Gerrans, G. C. 1994. Waist Deep in Waste-Reduce, Re-Use, Recycle. Spectrum; Vol. 32 (1): 32-36.

Hadker, N. 1995. Accounting for Informal Sectors: A Case Study of Solid Waste Management Systems in Bombay. Prepared for the ESCAP project on Environmental Accounting for India. Indira Ghandi Institute of Development Research, Bonbay (mimeo).

Jones, D.G. 1995. Environmental Improvement Through the Management of Waste.

Centre for Environmental Technology, Imperial College of Science and Technology. Business and the Environment - Practitioner Series. Stanley Thornes Ltd. United Kingdom.

Keep South Africa Beautiful Series, 1992a. Pretoria: Government Printer. 
Keep South Africa Beautiful Series, 1992b. Teachers Guide Part 10. Department of National Health and Population Development. Pretoria. Government Printer. Language, P. and Van Blerk, J. 2000. Recycling of Ferrochrome Furnace Bagfilter Dust at Samancor Chrome - A Success Story. Clear Air Journal. Vol. 10 (5): 15-22.

Leedy, P. D. 1993. Practical Research: Planning and Design. $5^{\text {th }}$ Edition. New York. MacMillan.

Lopes, C. 2002. Sustainable Development: Meeting the Challenges of the Millennium. In: CHOICES: Supplement, August 2002. World Summit on Sustainable Development, Johannesburg, South Africa. $26^{\text {th }}$ August $-4^{\text {th }}$ September 2002. Miller, G. T. 2002. Living in the Environment: Principles, Connections and Solution. Wadsworth Group Brooks / Cole, $12^{\text {th }}$ Edition.

Mitchell, M. and Jolly, J. 1992. Research Design Explained. Second Edition. Forth Worth. Harcourt Brace Jovanovich College Publishers

Mitra, J. and Hale, M. 1993. Education and Training for Sustainable Development: Strategies for Higher Education Institutions. In: Bandhu, D., Bongartz, H., Ghaznawi, A. G. and Gopal, B., (eds), Environmental Education for Sustainable Development. Proceedings on the Global Forum '93: Environmental Education for Sustainable Development, New Delhi, $24^{\text {th }}-28^{\text {th }}$ September, 1993.

Neal, P. and Palmer, J. 1990. Environmental Education in the Primary School. Oxford: Blackwell.

Neuman, W. L. 2000. Social research Methods: Qualitative and Quantitative Approaches. Fourth Edition. London: Allyn and Bacon.

Orr, D. W. 1992. Ecological Literacy: Education and the Transition to a Postmodern World. State University of New York Press. pp. 3 - 23.

Palmer, J.A. 1998. Environmental Education in the $21^{\text {st }}$ Century: Theory, Practice, Progress and Promise. Routledge, London and New York. pp. 35 - 77.

Palmer, J. A. and Suggate, J. 1996. Influences of Experiences Affecting the ProEnvironmental Behaviour of Educators. Environmental Education Research, 2(1): $109-122$.

Poate, C. D. and Daplyn, P. F. 1993. Data for Agrarian Development. Wye Studies in 
Agriculture and Rural Development. Cambridge University Press, UK. RSA (Republic of South Africa), 1999. National Waste Management Strategies and Action Plans South Africa. Action Plan Development Phase, Action Plan for General Waste Collection, Version C. PMG 132, PSC 71. Department of Environmental Affairs, Pretoria.

Ryan, P. 2000. The Great Plastic Bag Debate: Is the Ban on Plastic Bags the Answer? African Wildlife. Vol. 54 (6): 7-10.

Sachs, W., Reinhard, L.and Linz, M. 1998. Greening the North: A Post-Industrial Blue Print for Ecology and Equity. Zed Books Ltd., London, New York.

Schwarz, C. (ed), 1993. The Chambers Dictionary. Chambers Harrap Publishers Limited. London.

Shah, G. 1997. Public Health and Urban Development: The Plague in Sarat. Sage Publication. New Delhi.

Simmons, I. G. 1996. Environmental Thought: The Last 25 Years. International Journal of Environmental Studies, 29: 163 - 170.

Smarck, K. 1997. Martin Creamer's Engineering News. Vol. 17 (10); 65.

State of the Environment Report, 2002. South Africa Environmental Indicators, Pretoria: Internet: http://www.ceroi.org/reports/pretoria/issues/qual env lindicat.htm

Statistics South Africa, 2001. Census Data. http://www.statssa.gov.za/census01/ Census/Dialog/Saveshow.asp [accessed July 1, 2005])

Stoker, D. J. 1989. Basic Sampling Methods in HSRC: Survey Methods and practice. Modulez, HRSC: Opinion Survey Centre.

Struwig, F. W. and Stead, G. B. 2001. Planning, Designing and Reporting Research. Cape Town: Masker, Miller and Longman.

Swilling, M. and Hutt, D. 1999. Johannesburg South Africa. In: Onibokun, A. G. 2002 (ed), Managing the Monster: Urban Waste and Governance in Africa. International Development Research Centre. Ottawa, Cairo, Dakar, Johannesburg, Montivideo, Nairobi, New Delhi and Singapore.

Teurlings, P. 1993. Guide to Legislation Concerning Pollution. Pretoria: Government Printer. 
The World Fact Book, 2003. http://www.cia.gov./cia/publications/factbook/geos/sf.html Tilbury, D. 1992. Environmental Education within Pre-Serviced teacher Education:

The Priority of Priorities. International Journal of Environmental Education and Information, Vol. 11, 267 - 280.

UNCED (United Nations Convention on Environment and Development), 1992.

Agenda 21, Convention to Combat Desertification. Rio de Janeiro.

UNEP (United Nations Environmental Programme), 1994. Environmental Data Report 1993/1994. A Report for Global Environmental Monitoring System. Brazil.

Blackwell, Oxford, UK.

UNEP (United Nations Environmental Programme), 2002. Environmental Data Report 2000/2001. A Report for Global Environmental Monitoring System. Brazil.

Blackwell, Oxford, UK.

UNFPA (United Nations Fund for Population Assessment), 1999. State of World

Population: Sub-Saharan Africa: http://www.unfpa.org/africal: accessed July 3 2005)

UN-Habitat (United Nations Centre For Human Settlements), 1988. Refuse Collection

Vehicles For Developing Countries. HS/138/88 E.

Van Beukering, P., Sehker, M., Gerlagh, R., and Kumar, V. 1999. Analysing Urban

Solid Waste in Developing Countries: A Perspective on Bangalore, India. International Institute for Environment and Development (IIED). Working Paper No. 24. CREED Working Paper Series. Amsterdam.

Waltz, C. and Bausell, R. B. 1981. Nursing Research: Design, Statistics and Computer Analysis. Philadelphia: F A Davis.

World Resources Foundaton, 1997. Information Sheet: Paper Making and Recycling. Warmer Bulletin, No. 55.

\section{Further internet website references in the order of appearance in the text}

1. http://www.cielap.org/infocent/research/swaste.html (accessed on 15 June 2005).

2. http://usinfo.gov/journals/itgic/0300/ijge/gi05.htm (accessed on 8 June 2005)

3. (http://www.environment.gov.za/PolLeg/Agreements/2003Apr30/green leaders 30 042003.html (accessed on 9 August 2003). 
4. http://www.environment.gov.za/NewsMedia/MedStat/2003May5/plastic bags 05052003.html [accessed 9 August 2003]).

5. http://www.cia.gov./cia/publications/factbook/geos/sf.html (accessed 9 August 2003)

6. http://www.ceroi.org/reports/pretoria/issues/qual env /indicat.htm (accessed 9 August 2003)

7. http://www.envolironment.gov.za (accessed 27 June 2005)

8. http://www.gov.za/gazette/whitepaper/2000/20978.pdf (accessed 27 June 2005)

9. http://www.statssa.gov.za/census01/html/C2001SumReport.asp (accessed 27 June 2005). 


\section{ANNEXURES}

\section{ANNEXURE 1: DETAILED RESEARCH QUESTIONS OF THE STUDY}

\section{The Research Questions}

The detailed research questions of the study are summarized as:

1. What is the level of awareness among people in the Tshwane Metropolitan Area (TMA) about proper domestic waste disposal and recycling?

2. What are the relevant factors that influence peoples' incentives to adopt proper waste disposal and to recycle domestic waste?

3. Is there any relationship between level of environmental education (or environmental awareness) and attitude towards proper domestic waste disposal?

4. What is the relevance of social and economic factors (e.g. education, incomes, wealth, location, etc) in influencing people's attitudes towards proper domestic waste disposal?

5. What are possible state intervention mechanisms that could facilitate household participation in proper domestic waste disposal and recycling in the Tshwane Metropolitan Area (TMA)?

\section{ANNEXURE 2: SURVEY QUESTIONNAIRES USED IN THE STUDY}

Agnes J. KAMARA, Student No. 33767335

MEd Thesis Work at UNISA; Pretoria, South Africa (May - June 2004)

NOTE:

1. This information is used purely for study purposes at UNISA. The study will not reveal names of respondents, nor will the information be interpreted in ways that will reveal the identity of respondents.

2. The study is an environmental education study and will thus require information on awareness and participation in waste management, domestic solid waste disposal, recycling and attitudes towards the environment. 
1) Questionnaire No. ;Suburb: Lynnwood, Sunnyside, Mamelodi, Waterkloof, (please tick $\checkmark$ whichever is applicable)

2) Occupation: ; self-employed:

(Based on observation of assets related to Question 6, the interviewer is to classify the respondent into wealthy, middle class, poor (please circle)]

2a) Education: (years in school, college, training, etc)

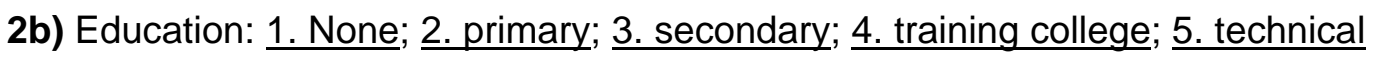

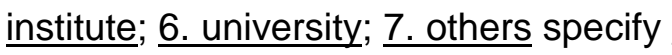
(tick $\checkmark$ as many numbers as possible)

3) Age of respondent: ; Gender:

4) Household Size: ; No. of Children in Household: (even if they are not your biological children). No. of old people:

5) Main sources of income: a) (over 60 years)

5a) Other sources of income: a) b)

5b) Annual income bracket: a) above R 50,000.00, b) between R10,000.00 and $\mathrm{R} 50,000.00$; and c) less than R 10,000.00 (please circle only one response: which ever applies)

6) Do you own any of the following: vehicle, radio, TV, Video, Others:

7) What do you do to ensure proper disposal of your domestic waste?

8) What do you think is the importance of waste sorting? (please circle the response)

a)

b)

c)

d)

8a) Where do you dispose of the following domestic wastes?

a) decomposable wastes (e.g. vegetable peels, food remnants, etc;

b) plastics (e.g. shopping plastic bags, etc.

c) cartons, empty boxes,

d) empty tins,

e) bottles,

f) scrap metal,

g) Others (specify), 
8b) Are you currently paying for your garbage disposal system?

\section{9) Do you sort your garbage?}

If yes, why do you sort? (circle whichever that applies)

\section{Responses:}

i) Because I see others doing it.

ii) I know that sorting could be useful (for what: recycling? compost? others?).

iii) I know that sorting will reduce environmental problems (e.g. volume of waste disposable waste? etc.

iv) I have seen it in the news (TV, radios, newspaper - please tick)

v) I see neighbours doing it, that is why I do it.

vi) I use some of the material myself (For what:

vii) I don't see any use for sorting my waste. It's a waste anyway.

viii) other reasons:

If NO, why NOT? (Circle whichever that applies)

\section{Responses:}

i) I don't know about it.

ii) I know about it but there is no garbage container nearby.

iii) I know about, there is a container nearby, but I don't have time to sort.

iv) I don't think it makes a difference to sort.

v) vi): other reasons:

vi) vii): other reasons:

\section{9a) When do you sort your garbage?}

a) When I have a party.

b) When I have the time, because I know it's important.

c) When I feel like, because it's really not important.

d) When I think I will be paid for certain components of my garbage.

(Go to question 10 and 10a if the person IS NOT SORTING garbage; or to question 10b and 10c if the person IS SORTING).

\section{0) FOR THOSE WHO DON'T SORT:}

I will start sorting: 
i) If I know about the health and environmental benefits of good waste management. (yes, no)

ii) I will start sorting if garbage containers are available in neighborhood or in my house. (yes, no)

iii) I don't think I have time to sort even if containers are available. (yes, no)

iv) I will start sorting if others will also do it. (yes, no)

v) Others:

vi) Others:

vii) Others:

10a) What do you think should be done to encourage you more to start sorting or avoid dumping around? Explain: (use the attached

supplementary sheet if necessary)

\section{0b) FOR THOSE WHO SORT:}

Problems encountered with sorting:

i) No containers: (please explain:

ii) Collectors don't come on time: (please explain:

iii) Little time for me to do so (please explain:

iv)

v) Others: (please explain:

vi)

vii) Others: (please explain:

viii) Others: (please explain:

ix) Others: (please explain:

10c) What do you think should be done to encourage you more to continue sorting or avoid dumping around? Explain: 
supplementary sheet if necessary)

11) FOR ALL RESPONDENTS: How do you feel about the current situation of solid waste disposal, dumping, sorting, etc.? please explain

(use the attached supplementary sheet if necessary)

12) What do you think could be done to help the situation?

(use the attached supplementary sheet if necessary)

12a) What would you do to achieve your suggestion in question 12 ?

(use the attached supplementary sheet if necessary)

13) What role do you think the City Council of Tshwane should play to ensure full participation of households in proper domestic waste disposal?

(use the attached supplementary sheet if necessary)

14) Is there any other thing you want to discuss regarding this domestic waste disposal and recycling in TMA?

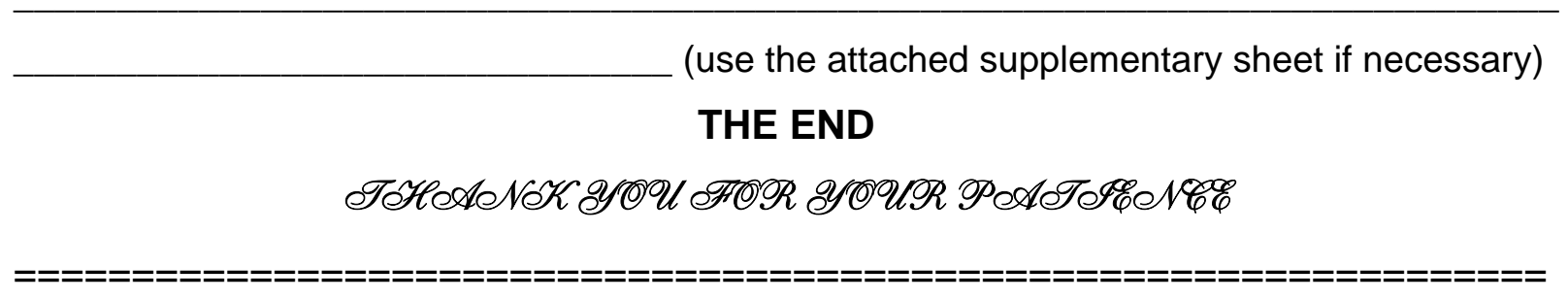




\section{ANNEXURE 3: $\quad$ EDUCATIONAL CATEGORIES OF RESPONDENTS}

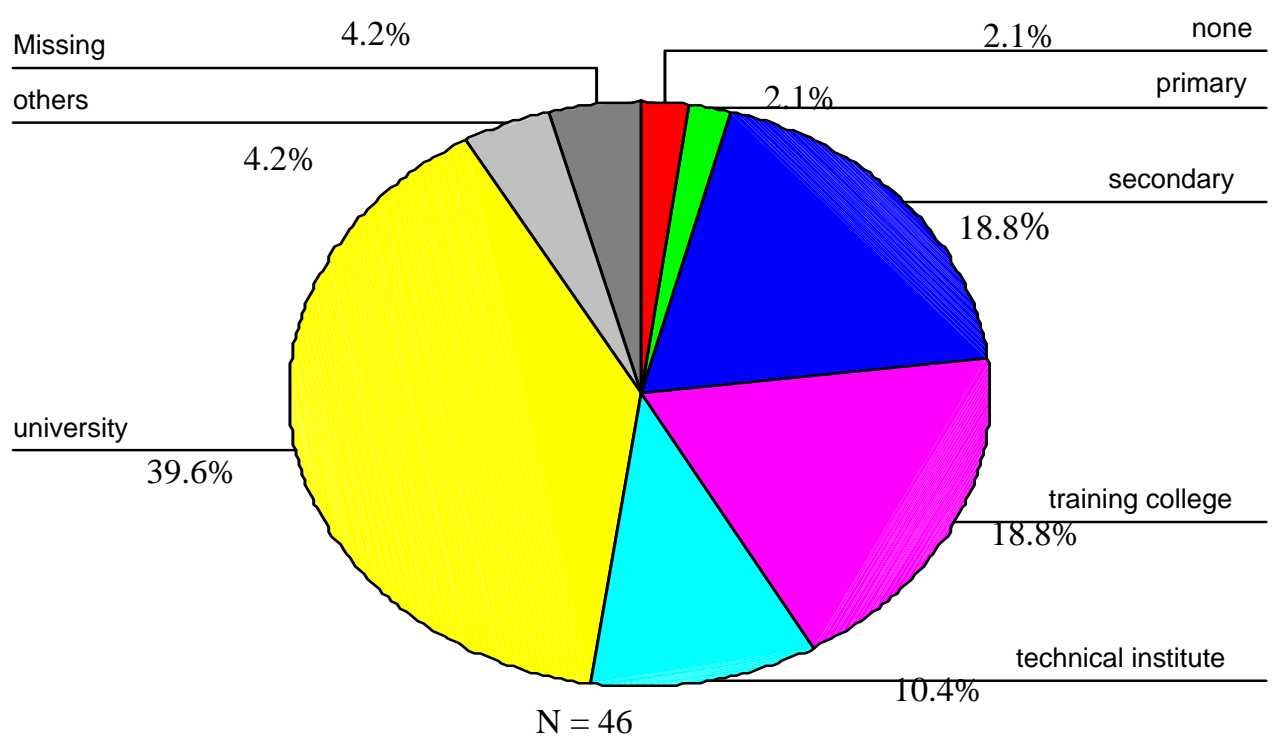

Source: Author, Field Survey, 2004

ANNEXURE 4: DETAILED HOUSEHOLD CHARACTERISTICS BY EDUCATION

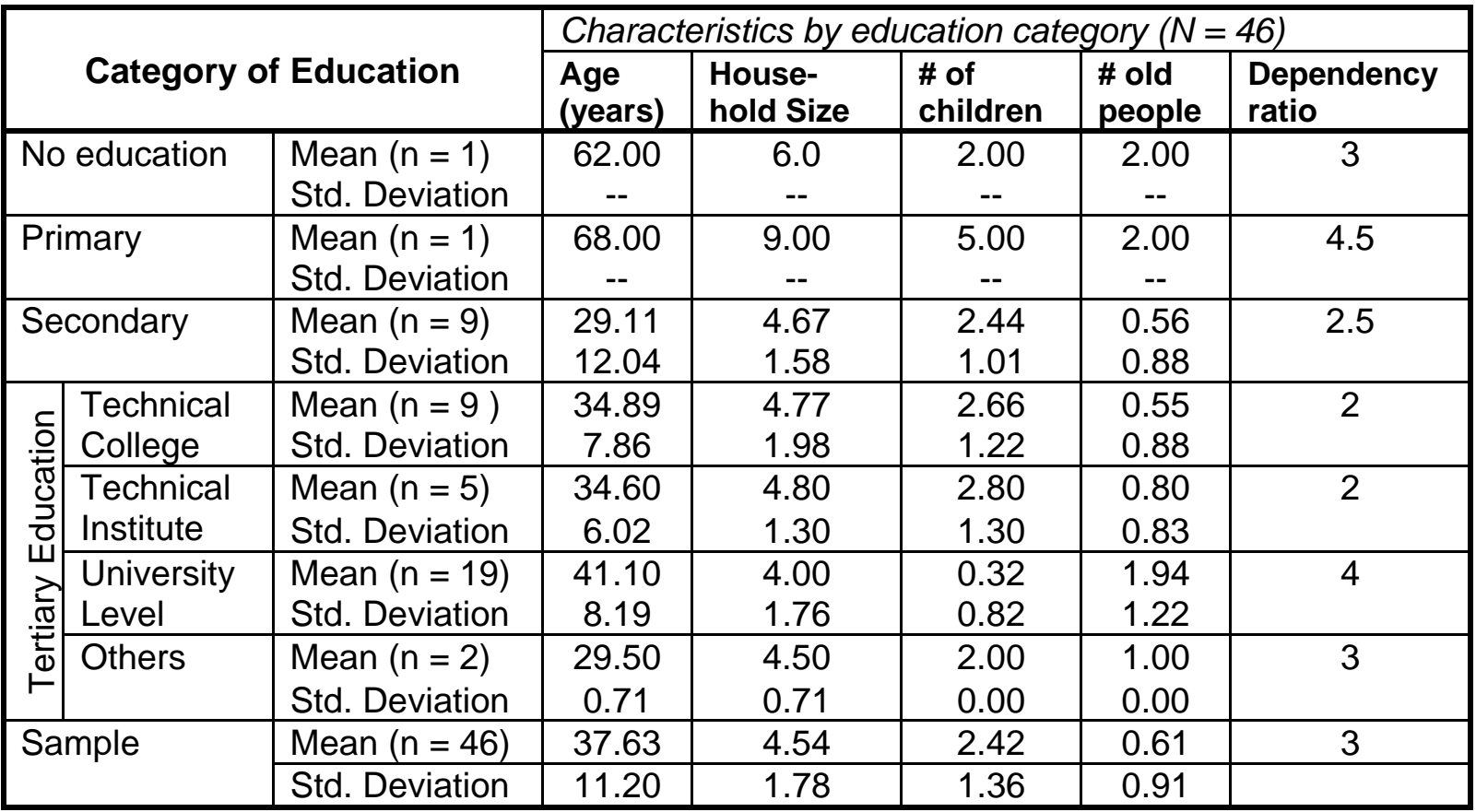

Source: Author, Field Survey, 2004 


\section{ANNEXURE 5: OCCUPATIONAL CATEGORIES OF SAMPLE HOUSEHOLDS}

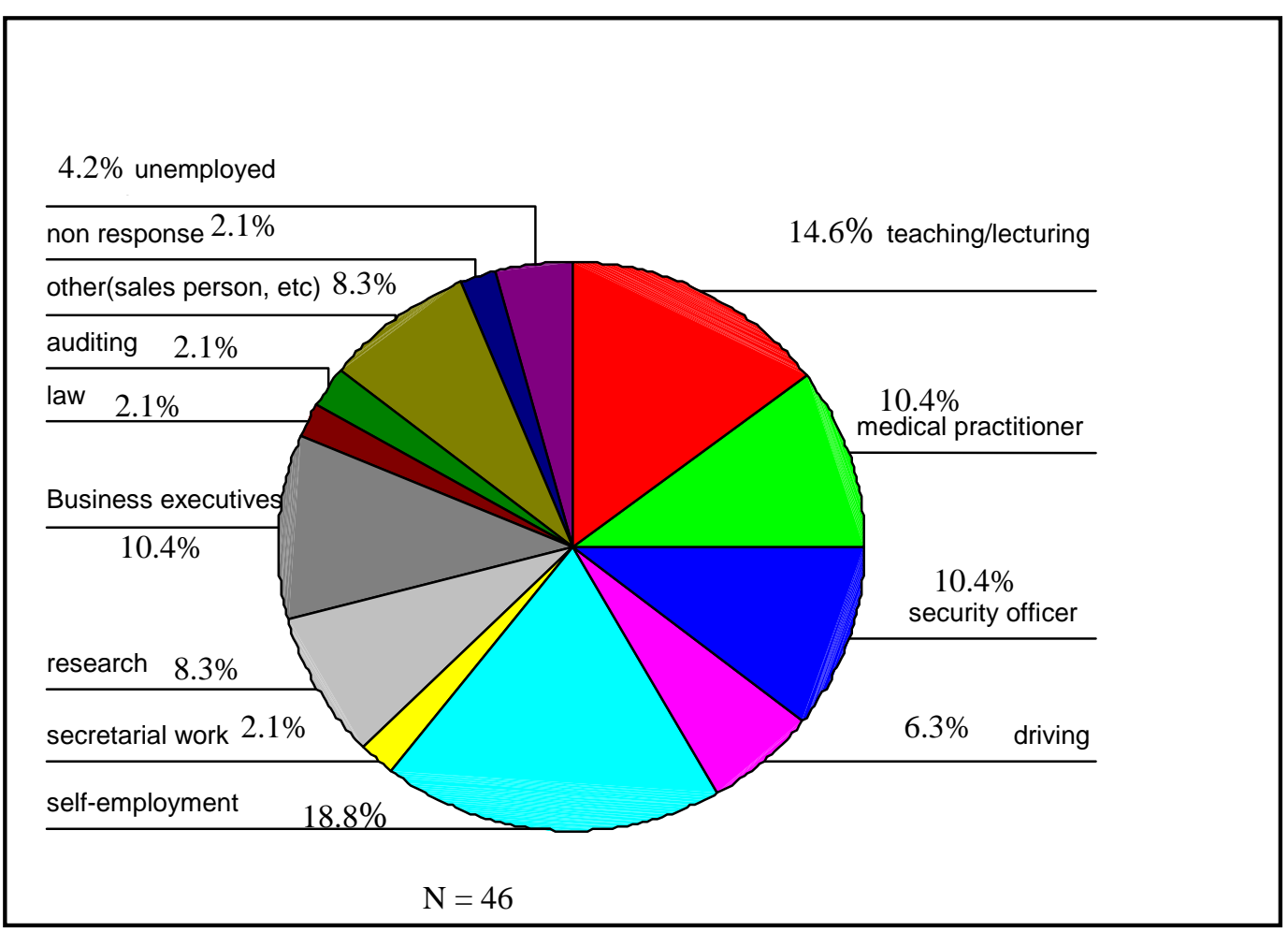

Source: Author, Field Survey, 2004

\section{ANNEXURE 6: REASONS FOR NON-PARTICIPATION OF HOUSEHOLDS IN DOMESTIC WASTE SORTING}

\begin{tabular}{llcc}
\hline No. & Response Category & Frequency & Percentage \\
\hline 1. I don't know & 5 & 10.86 \\
2. I know about it but there is no garbage container & 15 & 32.60 \\
3. I know there is a container but I don't have time to sort & 4 & 8.70 \\
4. I don't think it makes a difference to sort & 3 & 8.52 \\
5. Combined & 18 & 39.13 \\
$6 . \quad$ None Response & 1 & 2.17 \\
\hline & Total & 46 & 100 \\
\hline
\end{tabular}

Source: Author, Field Survey, 2004 
ANNEXURE 7: DETAILED HOUSEHOLD CHARACTERISTICS BY SUBURB AND INCOME CLASS

\begin{tabular}{|c|c|c|c|c|c|c|}
\hline \multirow{2}{*}{\multicolumn{2}{|c|}{ Variable }} & \multicolumn{5}{|c|}{ Detailed household characteristics by city suburb $(N=46)$ * } \\
\hline & & \multirow{2}{*}{$\begin{array}{c}\text { Lynnwood } \\
41.83 \\
4.02\end{array}$} & \multirow{2}{*}{$\begin{array}{c}\text { Sunnyside } \\
33.69 \\
7.36\end{array}$} & \multirow{2}{*}{$\begin{array}{r}\text { Mamelodi } \\
38.53 \\
12.07\end{array}$} & \multirow{2}{*}{$\begin{array}{c}\text { Waterkloof } \\
42.00 \\
11.58\end{array}$} & \multirow{2}{*}{$\begin{array}{r}\text { Sample } \\
37.63 \\
11.20\end{array}$} \\
\hline Age of respond (years) & $\begin{array}{l}\text { Mean } \\
\text { Std. Deviation }\end{array}$ & & & & & \\
\hline $\begin{array}{l}\text { Size household } \\
\text { (people) }\end{array}$ & $\begin{array}{l}\text { Mean } \\
\text { Std. Deviation }\end{array}$ & $\begin{array}{l}3.83 \\
1.94 \\
\end{array}$ & $\begin{array}{l}4.67 \\
1.98 \\
\end{array}$ & $\begin{array}{l}5.06 \\
1.48 \\
\end{array}$ & $\begin{array}{l}3.37 \\
1.30 \\
\end{array}$ & $\begin{array}{l}4.54 \\
1.78 \\
\end{array}$ \\
\hline $\begin{array}{l}\text { Total number of } \\
\text { children }\end{array}$ & $\begin{array}{l}\text { Mean } \\
\text { Std. Deviation }\end{array}$ & $\begin{array}{l}2.33 \\
0.81\end{array}$ & $\begin{array}{l}2.07 \\
1.25\end{array}$ & $\begin{array}{l}3.20 \\
1.42\end{array}$ & $\begin{array}{l}1.25 \\
0.88\end{array}$ & $\begin{array}{l}2.43 \\
1.36\end{array}$ \\
\hline $\begin{array}{l}\text { Total number of old } \\
\text { people }\end{array}$ & $\begin{array}{l}\text { Mean } \\
\text { Std. Deviation }\end{array}$ & $\begin{array}{l}0.16 \\
0.40\end{array}$ & $\begin{array}{l}1.00 \\
0.91\end{array}$ & $\begin{array}{l}0.60 \\
0.91\end{array}$ & $\begin{array}{l}0.37 \\
1.06\end{array}$ & $\begin{array}{l}0.86 \\
0.90\end{array}$ \\
\hline Dependency ratios (\%) & Mean & 4.0 & 2.5 & 5.0 & 3.0 & 3.3 \\
\hline \multirow{2}{*}{\multicolumn{2}{|c|}{ Variable }} & \multicolumn{5}{|c|}{ Detailed household characteristics by wealth classes $(\mathrm{N}=46)^{\star *}$} \\
\hline & & Wealthy & Middle Class & Poor & -- & Sample \\
\hline Age of respond (years) & $\begin{array}{l}\text { Mean } \\
\text { Std. Deviation }\end{array}$ & $\begin{array}{c}39.83 \\
7.44\end{array}$ & $\begin{array}{l}39.45 \\
8.43\end{array}$ & $\begin{array}{l}34.77 \\
11.39\end{array}$ & $\begin{array}{l}-- \\
--\end{array}$ & $\begin{array}{l}37.36 \\
11.20\end{array}$ \\
\hline $\begin{array}{l}\text { Size household } \\
\text { (people) }\end{array}$ & $\begin{array}{l}\text { Mean } \\
\text { Std. Deviation }\end{array}$ & $\begin{array}{l}4.50 \\
0.83\end{array}$ & $\begin{array}{l}4.36 \\
2.10\end{array}$ & $\begin{array}{l}4.56 \\
1.59\end{array}$ & $\begin{array}{l}-- \\
--\end{array}$ & $\begin{array}{l}4.54 \\
1.78\end{array}$ \\
\hline $\begin{array}{l}\text { Total number of } \\
\text { children }\end{array}$ & $\begin{array}{l}\text { Mean } \\
\text { Std. Deviation }\end{array}$ & $\begin{array}{l}2.33 \\
1.03\end{array}$ & $\begin{array}{l}2.27 \\
1.42\end{array}$ & $\begin{array}{l}2.33 \\
1.11\end{array}$ & $\begin{array}{l}- \\
--\end{array}$ & $\begin{array}{l}2.43 \\
1.36\end{array}$ \\
\hline $\begin{array}{l}\text { Total number of old } \\
\text { people }\end{array}$ & $\begin{array}{l}\text { Mean } \\
\text { Std. Deviation }\end{array}$ & $\begin{array}{l}0.33 \\
0.81\end{array}$ & $\begin{array}{l}0.72 \\
0.98\end{array}$ & $\begin{array}{l}0.77 \\
0.97\end{array}$ & $\begin{array}{l}- \\
--\end{array}$ & $\begin{array}{l}0.61 \\
0.91\end{array}$ \\
\hline Dependency ratio & Mean & 2.25 & 3.0 & 3.0 & -- & 3.3 \\
\hline
\end{tabular}

* Lynnwood $(n=6) ;$ Sunnyside $(n=13) ;$ Mamelodi $(n=15) ;$ Waterkloof $(n=8) ;$ No response $(n=4)$

** Wealthy $(n=6)$; Middle Class $(n=22)$; Poor $(n=9)$; No response $(n=9)$

Source: Author, Field Data, 2004 
ANNEXURE 8: PARTICIPATION OF HOUSEHOLDS IN DOMESTIC WASTE SORTING

\begin{tabular}{l|cc}
\hline No. Response Category & $\begin{array}{c}\text { Frequ- } \\
\text { ency }\end{array}$ & $\begin{array}{c}\text { Percen- } \\
\text { tage }\end{array}$ \\
\hline \multicolumn{1}{c}{ I will start sorting if: } & & \\
1. I know about the health and environmental benefits of sorting & 16 & 34.78 \\
2. Garbage containers are available in the neighbourhood or nearby & 17 & 36.95 \\
3. Others will also do it $\quad$ I will not sort & 2 & 4.35 \\
4. I don't think I will have time to sort even if containers are available & 11 & 23.91 \\
\hline Total & 46 & 100 \\
\hline
\end{tabular}

Source: Author, Field Survey, 2004

\begin{tabular}{|c|c|c|c|}
\hline \multirow[t]{2}{*}{ ANNEXURE 9: } & \multicolumn{3}{|c|}{$\begin{array}{l}\text { WHAT DO YOU THINK SHOULD BE DONE TO ENCOURAGE } \\
\text { MORE PEOPLE TO PARTICIPATE IN DOMESTIC WASTE } \\
\text { SORTING AND MANAGEMENT? }\end{array}$} \\
\hline & No. Response Category & $\begin{array}{c}\text { Frequ- } \\
\text { ency }\end{array}$ & $\begin{array}{l}\text { Percen- } \\
\text { tage }\end{array}$ \\
\hline \multicolumn{2}{|c|}{ 1. Education on domestic waste sorting and its benefits } & 21 & 45.62 \\
\hline \multicolumn{2}{|c|}{ 2. Provision of enough garbage containers in households and streets } & 15 & 32.61 \\
\hline \multicolumn{2}{|c|}{ 3. Provision of a good and effective waste collection system } & 5 & 10.87 \\
\hline \multicolumn{2}{|l|}{ 5. Combined } & 2 & 4.35 \\
\hline \multicolumn{2}{|c|}{ 6. None Response } & 3 & 6.52 \\
\hline Total & & 46 & 100 \\
\hline
\end{tabular}

Source: Author, Field Survey, 2004 